\title{
Diversity of experience and labor productivity in creative industries
}

\author{
Orsa Kekezi ${ }^{1,2^{*}}$ (1)
}

\begin{abstract}
This paper studies how the previous experience among workers relates to the labor productivity of the creative industries in Sweden. Effective knowledge transfers are dependent on the cognitive distance among employees. Using longitudinal matched employer-employee data, I measure the portfolio of the skills within a workplace through (i) the workers' previous occupation, and (ii) the industry they have been working in previously. Estimates show that diversity of occupational experience is positive for labor productivity, but the diversity of industry experience is not. When distinguishing between related and unrelated diversity, the relatedness of occupational experience is positive for labor productivity, while unrelated occupational experience instead shows negative relationship with productivity. These results point towards the importance of occupational skills that workers bring with them to a new employment, for labor productivity.
\end{abstract}

Keywords: Diversity, Skill relatedness, Previous experience, Labor mobility, Knowledge spillovers

JEL classifications: J24, L25

\section{Introduction}

Research has often focused on the importance of different forms of human capital and firm performance (Delgado-Verde et al. 2016; Siepel et al. 2017). However, the productivity of workers within a firm also depends on who they work with (Mas and Moretti 2009; Card et al. 2013; Arcidiacono et al. 2017; Neffke 2017). The question that then arises is how the composition of skills relates to firm performance. The purpose of this paper is to examine how the diversity of skills which come from previous experience within a plant matters for labor productivity. I specifically focus on the diversity of skills which arises from previous work experience and labor productivity in terms of (i) their previous occupation, and (ii) the industry they have been working in. Since the work of Becker (1962), researchers have argued about the importance of industry-specific and occupational-specific human capital that people accumulate during their working life on

\footnotetext{
*Correspondence: orsa.kekezi@sofi.su.se

1 SOFI, Stockholm University, Stockholm, Sweden

Full list of author information is available at the end of the article
}

earnings and productivity (Parent 2000; Gathmann and Schönberg 2010; Sullivan 2010). ${ }^{1}$ As people move across jobs they bring some knowledge which was specific to what they were previously doing to the new employment (Almeida and Kogut 1999). From a theoretical standpoint, the diversity of the workforce could foster creativity and innovation, where new knowledge is created from the recombination of differentiated skills (Schumpeter 1934; Penrose 1959). However, if skills are too different, misunderstandings and conflicts can arise, which would lead to negative effects on performance.

Moreover, for knowledge spillovers and learning to happen, workers in a firm, need to have some sort of cognitive proximity among each other (Nooteboom 2000). Along these lines, I further define diversity by distinguishing between the relatedness and unrelatedness of experience. While previous literature in these lines measures the relatedness of skills through either educational background (Boschma et al. 2009), previous industry experience (Timmermans and Boschma 2014), or previous occupational experience (Östbring et al. 2017), it is

${ }^{1}$ Becker (1962) initially discussed firm-specific human capital, but that is not the focus of this paper.
Springer Open

(c) The Author(s) 2021. This article is licensed under a Creative Commons Attribution 4.0 International License, which permits use, sharing adaptation, distribution and reproduction in any medium or format, as long as you give appropriate credit to the original author(s) and the source, provide a link to the Creative Commons licence, and indicate if changes were made. The images or other third party material in this article are included in the article's Creative Commons licence, unless indicated otherwise in a credit line to the material. If material is not included in the article's Creative Commons licence and your intended use is not permitted by statutory regulation or exceeds the permitted use, you will need to obtain permission directly from the copyright holder. To view a copy of this licence, visit http://creativeco mmons.org/licenses/by/4.0/. 
all of them which make up the skills of individuals. To my knowledge, the only previous study which considers multiple measures of skills is the one of Östbring et al. (2018) who use both education and previous industry experience. However, occupations are crucial to add as they are proxies of skills and abilities of the workforce beyond the educational background (Bacolod et al. 2009). What people work with is sometimes argued to be more important than their educational degree (Florida 2002). Hence, this paper contributes to the existing literature by proxying the diversity of skills within a workplace through their previous work experience, since people can bring with them both industry-specific knowledge but also occupational-specific one. By disentangling the type of skills and experience brought into the firm, we can get a deeper understanding of the micro-mechanisms of knowledge transfer, knowledge spillovers, and labor productivity.

This paper also contributes to the literature by applying this research question on creative industries, which are the focus for several reasons. ${ }^{2}$ First, as knowledgeintensive industries, they rely heavily on knowledge as an input. Labor creativity is the main factor of production (Florida 2002), and they are characterized by talented and high-ability individuals and firms which create new knowledge (Larsen 2001; And and Isaksen 2007). Employment in such industries is also inherently autonomous and more self-expressive than more traditional workplaces (Howkins 2002; Florida 2002). Second, creative industries are characterized by a project-based production system and the production is dependent on the interaction of multiple agents (Caves 2000), who work in teams which are put to work together for a short time (Jarvis and Pratt 2006). Interactions among employees are a crucial assumption when studying diversity within a firm, because for productivity to be affected workers need to work together or to interact with each other for learning to happen. Given the high probability that workers within firms in creative industries work together to produce something, they become an interesting case of study. Yet, their skill decomposition has not been extensively studied, with a few exceptions (Taylor and Greve 2006). Third, creative industries are widely seen in the literature as being innovative and the within-firm decomposition is an important determinant of innovation (Castañer and Campos 2002; Protogerou et al. 2017). Last, by focusing on a similar set of industries, I am also able to mitigate issues arising from sectoral heterogeneity, which has been shown to give different results regarding the importance of diversity and relatedness on firm

\footnotetext{
${ }^{2}$ Table 8 in the Appendix presents the list of industries included, adapted from Miguel-Molina et al. (2012).
}

performance (Östbring et al. 2018). To sum up, combining the project-based type of work, with labor-intensity in production, as well as a high innovative potential, creative industries become a good case of study for issues regarding the diversity of human capital and labor productivity. It is also important to note that with the increasing focus on the knowledge economy, creative industries are an important sector for regional development (Florida 2002; UNESCO 2013). ${ }^{3}$ Thus, understanding how these sectors become more productive and grow has implications for the economy at large.

To answer the research questions, I use longitudinal matched employer-employee yearly data from 2007 to 2016 for all the firms and individuals employed in creative industries in Sweden. I track the current employees 5 years back to see what type of experience they had. The diversity of skills is measured through a fractionalization index. To disentangle whether diversity is related or unrelated, I use the relatedness index proposed by Neffke and Henning (2013), which is based on labor flows. Results show that the diversity of occupational experience is positive for labor productivity, but the diversity of industry experience is not. Second, the unrelatedness of industry and occupational experience are both negative for labor productivity. On the other hand, the relatedness of occupational experience within the workplace is positive for firm performance. Third, when experience is measured as a combination of industry and occupation, the relatedness of the two is positive and strongly related to productivity. These results point towards the importance of occupational specific skills for labor productivity and indicate that the positive relation between the diversity of the workforce and productivity is mostly driven by relatedness.

The paper is organized as follows. Section 2 describes the theoretical framework and previous literature on skills, knowledge spillovers and growth. Section 3 presents the data and variables. In Sect. 4 empirical findings and analysis of the results are shown, and in Sect. 5 the stability of the results is checked. Section 6 concludes.

\footnotetext{
3 Table 9 in the appendix shows the characteristics of plants that belong to creative industries (as defined on the paper) and the plants that do not for 2007 and 2016 which is the time studied empirically. The data show that creative industries have experienced a much larger growth in terms of employment, number of plants, as well as sales. Productivity growth does not differ between the two groupings, but the growth of wages is lower for creative industries. The growth rate of the creative industries during this time period shows that they are an important segment of the Swedish economy, which is growing fast, and it employed about 9 percent of the workforce in 2016.Moreover, they also indirectly support the economy by for example facilitating and supporting innovation for other sectors in the economy (Müller et al. 2009).
} 


\section{Diversity, relatedness, and firm performance}

Research on workforce diversity and firm performance, broadly defined, is extensive. Some researchers have used case studies and focused on team diversity (Horwitz and Horwitz 2007) as well as the composition of the top management and founding team (Bantel and Jackson 1989; Pitcher and Smith 2001; Visintin and Pittino 2014). Others have used linked employer-employee data to examine the within-firm diversity (Söllner 2010; Østergaard et al. 2011; Parrotta et al. 2014a, b; Solheim et al. 2020). On the one side, the diversity of skills contributes to the creation of new ideas and thus better performance (Bantel and Jackson 1989; Lazear 1999; Taylor and Greve 2006; Berliant and Fujita 2011). Firms with more diverse knowledge bases also have higher "absorptive capacity", i.e. accumulated knowledge to understand and use the new, incoming one, which is crucial for innovation and growth (Cohen and Levinthal 1990). On the other side, for certain tasks, Kremer's O-ring predicts that workers with similar skills should work together to see higher productivity returns (Kremer 1993). Moreover, people might prefer working with others whom they see as similar. If diversity leads to misunderstandings, conflicts, or uncooperativeness across workers, negative effects of diversity are observed (Bassett-Jones 2005; Jehn et al. 1999; Madsen et al. 2003; Williams and O'Reilly 1998). Thus, how diversity impacts firm performance is an empirical question.

In a theoretical contribution, Lazear (1999) argues however that for diversity to have a positive effect on performance, the skills of the workforce should be disjoint but still relevant to one another. Moreover, they should be learnt by the other groups at a not too high cost. Thus, for learning to happen, some level of cognitive proximity or complementarity is required (Nooteboom 2000). If the knowledge bases of the firm are too different, people do not understand each other. Yet, too much cognitive proximity might create a lock-in problem that disables the capability of companies to adopt new technologies or market possibilities (Boschma 2005). Nooteboom et al. (2007) find for instance an inverted U-shaped impact of the cognitive distance and innovation of firms, indicating that knowledge shouldn't be too similar or too different for innovation to happen. To take the cognitive distance into account, the notion of relatedness has emerged in the literature, where several studies, stemming from the work of Frenken et al. (2007), have distinguished between related and unrelated diversity (Boschma et al. 2009; Östbring and Lindgren 2013; Östbring et al. 2017, 2018).

When examining the effect of skill diversity on firm performance, most existing studies focus on the diversity of educational background, where the results often show a positive effect (Østergaard et al. 2011; Parrotta et al. 2014b, a). Boschma et al. (2009) look deeper at the type of educational diversity within firms and find evidence that firms with higher education relatedness show higher productivity growth. Similar results are found in Östbring and Lindgren (2013), and the effect is stronger for labor-intensive industries than capital-intensive ones.

However, proxying skills of the workforce through education has not come without critique in the literature, since the quality of education is heterogenous, not only across countries but also across regions within a country (Mulligan and Sala-I-Martin 2000; Ingram and Neumann 2006). Moreover, skills and human capital are to a large extent collected from the working-life experience, something that education does not capture. Becker (1962) discussed that human capital can be general which increases productivity no matter the job people have, but it can also be specific to the firm people are working. Specific human capital can therefore not be transferred across jobs. Extending Becker's work, literature has discussed that human capital is also industry (Neal 1995), or occupation-specific (Kambourov and Manovskii 2009). Thus, as people change industries or occupations, there are skills which cannot be transferrable. This indicates that if workers within a firm have very different skills, working together would not necessarily be beneficial as they would not understand each other, which goes back to the cognitive proximity argument (Nooteboom 2000).

A complementary measure of human capital often used in the literature is through different occupations that individuals had (Thompson and Thompson 1985; Florida 2002; Florida et al. 2008; Scott 2008). Occupations measure the practical skills of people, beyond their formal education (Bacolod et al. 2009; Wixe and Andersson 2016). The diversity of occupations within a firm has not been extensively studied, but the existing literature suggest a positive effect on innovation (Söllner 2010; Parrotta et al. 2014b). Östbring et al. (2017) further suggest that the positive effect of occupational diversity on productivity is driven by relatedness because the unrelatedness of occupations in a firm either displays insignificant or negative effect. Besides education and occupation, human capital can also come from industry experience (Neal 1995). Östbring et al. (2018) have studied how the relatedness of industry experience in knowledge-intensive business services impacts firm performance. Their results show that for single-plant firms, the variety of knowledge and previous industrial experience affect firm performance positively.

To sum up, the literature has previously investigated the importance of educational diversity, occupational diversity, or diversity of industrial experience on firm performance. Their results point toward a positive impact of diversity, but these effects seem to be stronger in the 
case of related diversity. Yet, Timmermans and Boschma (2014) find that it is the unrelatedness which matters for productivity growth of firms in the region of Copenhagen in Denmark. They speculate that it could be because Copenhagen is mostly characterized by service industries compared to the rest of Denmark, which might benefit mostly from unrelatedness. Therefore, we do not know a priori what type of diversity matter most for creative industries.

Moreover, these studies primarily study the diversity of the current occupation individuals have, and not at their occupational and industrial history. From a theoretical perspective, the knowledge of workers is also shaped by their previous experiences and job tasks. When people change jobs, the skills that they have accumulated are not necessarily left behind but instead brought into their new workplace (Almeida and Kogut 1999). While labor mobility has been extensively studied, we do not know enough on the type of knowledge and skills are brought into the firm and how that affects performance (Boschma et al. 2009; Timmermans and Boschma 2014). Therefore, the skills that people bring can come from their previous industry experience, from previous occupations they might have had, or from a combination of the two. Sullivan (2010) argues that human capital is both connected to the industry and occupation. Similarly, the literature on job polarization treats a "job" as an occupation-industry interaction (Autor et al. 2003; Goos and Manning 2007). The reason for using a combination of the two is that there are industry effects on wages, after controlling for the occupation. ${ }^{4}$

\subsection{Why employee diversity in creative industries?}

The literature covered so far does not specifically focus on creative industries, raising the questions on how it relates to them, as well as what can we learn from studying the diversity of skills in such sectors. Creative industries are a good case of study for this research question for several reasons.

Researchers have increasingly argued that workers in creative industries are likely to collaborate and work in teams (Caves 2000; Jarvis and Pratt 2006; Uzzi and Spiro 2005; Savino et al. 2017). Moreover, due to the projectbased character of these industries, the workforce if constantly required to readjust and form new teams since projects are often short-term, which can become

\footnotetext{
${ }^{4}$ In a related strand of literature, studies have indeed looked at the importance of industry or occupational experience (not combined) in a firm, for wages, firm survival as well as productivity (Timmermans and Boschma 2014, Martynovich and Henning 2018, Jara-Figueroa et al. 2018). However, the focus of these studies is on relatedness to the current job rather than relatedness across workers within the workplace.
}

particularly challenging in the smaller firms (Christopherson 2004; Hotho and Champion 2011). When it comes to the decomposition of the team, Taylor and Greve (2006) and Perretti and Negro (2007) find evidence that creative industries especially benefit from teams with diverse skills. Thus, the literature on firm diversity and firm performance discussed at the beginning of Sect. 2, is highly relevant and applicable to the creative industries. Moreover, because the probability of teamwork is higher in such industries, the results obtained would give a clearer and more accurate picture on the importance of diversity for knowledge spillovers and productivity.

Moreover, creative industries are characterized by high labor mobility (Florida 2002; Frederiksen and Sedita 2011). Florida (2002) also identifies creative workers as mobile in their career choices, since they have the skills and education to change jobs or careers. This can be directly connected to the structure of such industries which are characterized by a lot of small firms with high entry and exit rates (Power 2003). Thus, the probability that workers have previous experience from other industries and occupations is higher. Furthermore, they are labor intensive and they usually employ high-skilled individuals who create new knowledge (Larsen 2001; Wiig Aslesen and Isaksen 2007).

What is also important to note is that skills obtained from occupational experience are especially important for people working in creative industries. By definition, creative industries, are characterized by a high concentration of creative workers. Florida's (2002) creative class is based on the occupations people have and what they do in their everyday tasks, rather than the industries where they are employed. Moreover, the occupational distribution across industries can be heterogenous. For instance, a high-tech firm employs accountants, engineers, manufacturing jobs, as well as service jobs at the food court (Mellander 2009). Along these lines, Barbour and Markusen (2007) discuss that the occupational structure of high-tech industries in California is different from the rest of the US. Thus, these results hint towards the idea that industry-specific skills might not be equally important for creative industries.

\section{Data, variables, and method}

To examine the relatedness of the previously acquired skills among workers on labor productivity in the creative industries, I use register longitudinal matched employer-employee yearly data, collected from Statistics Sweden, during 2007-2016. To allow plants to reach some skill diversity, similar studies drop plants with less than 10 employees (Parrotta et al. 2014a, b). However, creative industries in are characterized by small firms which is clearly shown in Fig. 1 below. To 


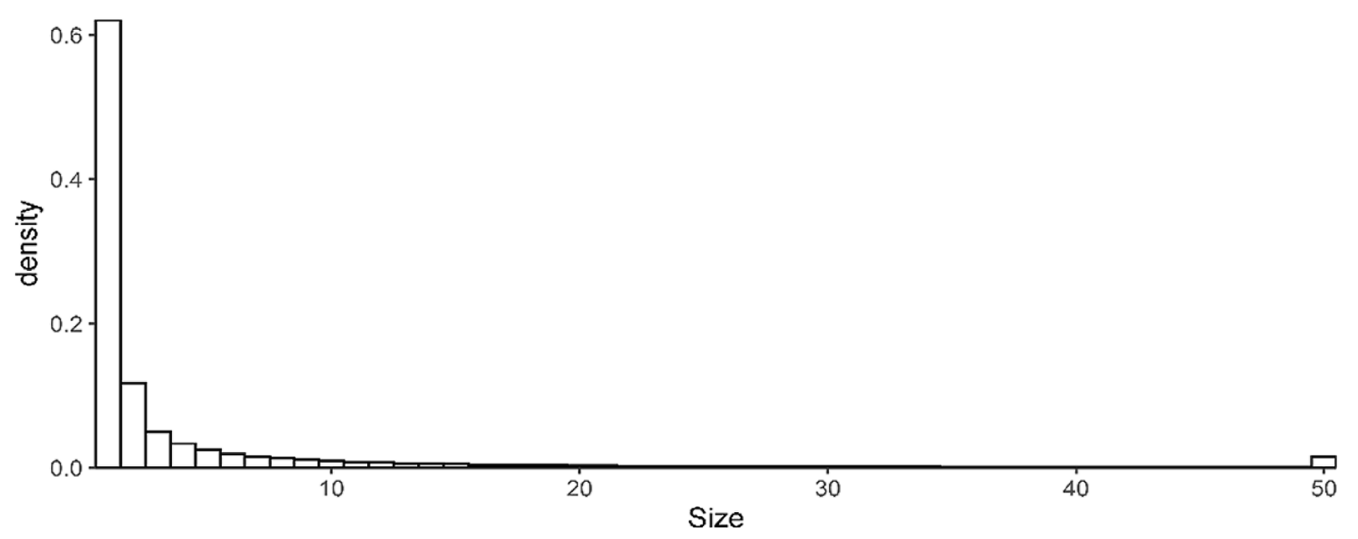

Fig. 1 Distribution of plant size

Table 1 The most common occupations and industries where workers employed in creative industries come from

\begin{tabular}{ll}
\hline Occupation & Industry \\
\hline Computing professionals & Computer programming activities \\
Physical and engineering science technicians & Computer consultancy activities \\
Architects, engineers and related professionals & Construction and civil engineering activities and related technical consultancy \\
Writers and creative or performing artists & Advertising agency activities \\
Finance and sales associate professionals & Industrial engineering activities and related technical consultancy \\
Managers of small enterprises & Business and other management consultancy activities \\
Shop, stall and market salespersons and demonstrators & Engineering activities and related technical consultancy in energy, environ- \\
Business professionals & ment, plumbing, heat and air-conditioning \\
Computer associate professionals & Architectural activities \\
Artistic, entertainment and sports associate professionals & Other software publishing \\
\hline
\end{tabular}

make the visualization clearer, all plant with more than 50 employees are put together in the last bar.

The figure shows the distribution of firm size, where about 62 percent of the firms only have one employee and an additional 12 percent have only two employees. To not exclude too many of the firms in the creative industries, and to be able to give a representative picture of the creative industries, I keep firms that have at least 3 employees, where at least some level of diversity is reached.

I track the current employees five years back in time to see what type of experience they had. If they have changed industries or occupation several times, the most recent is considered. If they have been working in the same industry and occupation in the past 5 years, the current job is considered. During the time of the study, the experience of the workers in creative industries comes from 113 different occupations and approximately 700 industries. Table 1 shows the 10 most common occupations and industries that the workers currently employed in creative industries have experience on.

\subsection{Variables and method \\ 3.1.1 Dependent variable}

The outcome variable is labor productivity, measured as value-added per employee, in its logged form. Previous research usually measures the effect of relatedness of skills on productivity growth with a time lag of more than one year due to the time it may take for the knowledge spillovers to influence growth. However, due to the project-based characteristics of some creative industries, the short-term effects of such spillovers are of interest. Thus, a one-year lag is implemented. Following Timmermans and Boschma (2014), for multi-plant firms, the value-added across plants is distributed according to the distribution of wages.

While measuring productivity through value-added is common, using value added for creative industries might be cumbersome (Maroto-Sánchez 2012). In broad terms, productivity refers at the ability of a firm to generate outputs from a set of inputs. Service sectors, in general, do not have the same inputs or outputs as the traditional manufacturing firms, creating so difficulties 
in measuring labor productivity (Van Ark 2002). Therefore, besides value added, results are also estimated using wages. Assuming that wages also reflect labor productivity (Becker 1964; Mincer 1974), a more efficient flow of knowledge across employees would indicate higher productivity and thus higher earnings.

\subsubsection{Measuring diversity and relatedness of skills}

In the first step, following Parrotta et al. (2014b), the diversity of skills is measured through a fractionalization index (Alesina et al. 2003) which is computed at the plant level as one minus the Herfindahl index:

$$
\text { Fract }_{w t}=1-\sum_{s=1}^{S} p_{w s t}^{2}
$$

where $w$ denotes the workplace, $s$ is the variable for which the diversity is computed, and $t$ is time. $p^{2}$ is square of the share of workers within each category $s$, each year. The index takes the minimum value of zero if there is only one category present in the workplace and its maximum value occurs when all categories are distributed equally: $\left(1-\frac{1}{S}\right)$. The index is measured for the diversity of occupational and industry experience.

Besides diversity itself, following the discussion presented in the literature review, it is also interesting to look at whether the degree of diversity matters. Frenken et al. (2007) proposed the entropy measures of related and unrelated variety, which have been often used in the literature to measure the degree of diversity within a firm (Boschma et al. 2009; Östbring and Lindgren 2013; Östbring et al. 2017, 2018). However, these measures are dependent on industry or occupational classifications which do not fully capture the degree of relatedness or cognitive proximity since they are arbitrarily decided (Essletzbichler 2015).

Therefore, to define related and unrelated industries and occupations, I rely on the revealed skill-relatedness (SR) measure proposed by Neffke and Henning (2013). ${ }^{5}$ The main assumption behind SR is that individuals are more likely to switch jobs across industries where their skills can partly be used. The steps described below follow the original paper and are based on the labor flows of the working population in Sweden. First, a matrix with pairwise labor flows for all 5-digit industry codes during 2004-2007 is constructed. Like in Neffke and Henning

\footnotetext{
${ }^{5}$ While the Neffke and Henning (2013) skills relatedness index is well-established in the literature, the index does not consider the geography of labor mobility. People are more likely to switch jobs in the areas where they live or work (Manning and Petrongolo 2017), thus industrial mobility is partly constrained to the industries available in the region. This concern does however not change the findings of the paper, neither the suitability of the skill-relatedness measure for the research question.
}

(2013), industry changes of individuals who earn less than the industry median wage as well as managers are excluded since these are individuals who are not very likely to have industry-specific skills. ${ }^{6}$ The intuition is that we want to capture industries that require similar skill sets. Inter-industrial moves of individuals who do not have industry specific skills, would not give us that information. I then run a zero-inflated negative binomial regression with pairwise industrial flows as the dependent variable. The independent variables are the employment size, average wage, as well as wage growth in the origin and destination industries. Using the point estimates obtained, the predicted labor flows are calculated for each industry pair. The SR measure is:

$$
S R_{i j}=\frac{F_{i j}^{o b s}}{\hat{F}_{i j}}
$$

where $F_{i j}^{o b s}$ and $\widehat{F}_{i j}$ are the observed and predicted flows respectively. A value of larger than 1 indicates that the observed flows are larger than predicted, making the industries related. A ratio of lower than 1 shows that the industries are skill dissimilar. In the last step, arguing that the probability for an individual to move from industry $i$ to $j$ is the following, it is possible to statistically test whether the observed flows are exceptionally large:

$$
\hat{p}_{i j}=\frac{\hat{F}_{i j}}{e m p_{i}}
$$

SR is significant and higher than 1 in 4 percent of all industry combinations. The NACE industrial classification changed in 2007, where the industries were split and aggregated differently, creating difficulties into translating the old industrial codes to the new ones. Thus, the skill-relatedness index is constructed in the same way for the new codes for labor mobility during the years 2010-2013. ${ }^{7}$

However, human capital is also dependent on the type of job workers have in the firm. Gathmann and Schönberg (2010) find that people are more likely to switch occupations across those jobs where they can use their skills more. Thus, the skill relatedness matrix is also constructed for the 3-digit occupational codes in the same way as explained above. The main difference between this calculation and the industrial relatedness one is that

\footnotetext{
${ }^{6}$ The empirical estimations are however relatively stable even when managers and people who earn less than median wage are included in the SR. They are available upon request.

7 Since the period studied is 2007-2016, for 2007-2010, the relatedness of experience is calculated through the old classification and for 2011-2016 with the new one.
} 
labor flows are not measured each year, but rather every second year. The reason is that Statistics Sweden does not collect data regarding occupations for the full population each year. After two years approximately 80 percent of the population is covered, which makes the occupational switches more reliable. About 13 percent of the combinations are statistically related to each other. ${ }^{8}$

Following the steps above, the industry- and occupation-pairs which are skill-related to each other are identified. To aggregate this to a plant level, I first identify all possible industry (and occupation) combinations of experience between workers within a plant. Then, the number of all combinations which are statistically significant with a SR above one is divided by the total number of combinations to calculate the share of relatedness in a firm. In the same way, the number of people with the same industry experience is divided by the total number of combinations. The rest is the share of skill unrelatedness in a firm. Since the three shares add up to one, the similarity of skills is not included in the estimations.

\subsubsection{Method}

To study how relatedness of skills relates to on average labor productivity, a linear regression model with fixed effects is used. The panel is not balanced, since firms can enter and exit during the time studied. As in many studies where the dependent is productivity, the starting point is often the Cobb-Douglas production function, where productivity of plant $i$ at time $t$ is a function of technology $(\mathrm{A})$, capital $(\mathrm{K})$, and labor $(\mathrm{L})$ :

$$
Y_{i t}=A L_{i t}^{\alpha} K_{i t}^{\beta}
$$

However, since I am interested in productivity per employee, we can divide everything by $\mathrm{L}$, allowing the Cobb-Douglas to take the following form:

$$
\frac{Y_{i t}}{L_{i t}}=y_{i t}=\frac{A L_{i t}^{\alpha} K_{i t}^{\beta}}{L_{i t}}=A L_{i t}^{\alpha-1} K_{i t}^{\beta}
$$

In order to facilitate the empirical estimation, the model is estimated in its logarithmic form where all the control variables were captured in the A parameter in the previous equations:

$$
\begin{aligned}
\ln y_{i t}= & \delta \ln L_{i t}+\beta \ln K_{i t}+\varphi_{1} D i v_{i t-1}+\varphi_{2} \ln \Gamma_{i t} \\
& +\varphi_{3} \ln Z_{r t}+\varphi_{4} D_{f}+\varphi_{5} D_{t}+u_{i t}
\end{aligned}
$$

where $\delta=\alpha-1$ and since $\alpha<1$ by definition, the coefficient of labor in this case is expected to be negative. $D i v_{i t-1}$ are the plant diversity and relatedness which are calculated with a time lag of one year to allow for the knowledge spillovers to take place. $\Gamma$ represents a vector of the plant specific control variables, and $Z$ represents the vector of the region-specific characteristics, $D_{f}$ and $D_{t}$ are fixed effects on the firm, and time.

One problem that the literature has pinpointed however, is that the error term consists of $\omega_{i t}$ which is a productivity shock observed by all firms but not by econometricians, while $\eta_{i t}$ is observed by both firms and econometricians as shown below:

$$
u_{i t}=\omega_{i t}+\eta_{i t}
$$

For that reason, the estimates observed by linear regressions usually show upward biases in the coefficient of labor and the coefficients for capital are downward bias. Thus, the methodology developed by Olley and Pakes (1996) (henceforth, OP). The OP estimation is a semi-parametric method which is calculated on the identification of a proxy variable which is assumed to be a function of $\omega_{i t}$ productivity shocks. The proxy variable is often investments which firm make, which are assumed to increase productivity. Therefore, they suggest the use of a control function approach, which controls for the endogeneity of labor, where investments are used to replace the unobserved productivity shock. Following Tao et al. (2019), investments are measured as the change of fixed assets. Similar two-step approaches have often been used in the literature to infer productivity by observing the input choices of the firms (Parrotta et al. 2014a; Serafinelli 2019; Tao et al. 2019).

\subsubsection{Control variables}

Following the Cobb-Douglas production function, labor and capital are included in the estimations. Besides, the diversity of educational background is also controlled for in the empirical model. The main reason for doing so is to ensure that our measures of diversity of work are not driven by the diversity of the education tracks. Previous literature has mostly found a positive effect between the diversity of education and labor productivity (Østergaard et al. 2011; Parrotta et al. 2014b, a). ${ }^{9}$ Share of workers with high education, plant age, and whether the firm is multi-plant or not are further controlled for in the model (Östbring and Lindgren 2013; Wixe 2015). Since knowledge can also be region-specific, to examine the importance of skills acquired in a different region (Timmermans and Boschma 2014; Boschma et al. 2009), the share of workers who have worked in another labor

\footnotetext{
${ }^{8}$ In 2014 the occupational codes changed, and the new codes were manually matched with the old ones.
}

\footnotetext{
${ }^{9}$ The education tracks are presented in respectively Table 10 in the Appendix.
} 
Table 2 List of Variables and descriptive statistics

\begin{tabular}{|c|c|c|c|c|c|}
\hline Variables & Measured as & Mean & SD & Min. & Max. \\
\hline \multicolumn{6}{|c|}{ Outcome variables } \\
\hline Avg_Prod (000) & Value added per labor & 937.217 & 7396.918 & 0.094 & $809,103.1$ \\
\hline Wages (00) & Average yearly wage in the plant & 3865.126 & 1366.513 & 3.667 & $25,718.73$ \\
\hline \multicolumn{6}{|c|}{ Diversity and relatedness measures } \\
\hline FRACT_occu & 1 minus the Herfindahl index of the diversity of occupation experience & 0.641 & 0.206 & 0 & 0.959 \\
\hline FRACT_ind & 1 minus the Herfindahl index of the diversity of industry experience & 0.568 & 0.245 & 0 & 0.976 \\
\hline Occ_R & Share with related occupation experience & 0.44 & 0.231 & 0 & 1 \\
\hline Occ_U & Share with unrelated occupation experience & 0.313 & 0.238 & 0 & 1 \\
\hline Ind_R & Share with related industry experience & 0.318 & 0.229 & 0 & 1 \\
\hline Ind_U & Share with unrelated industry experience & 0.337 & 0.255 & 0 & 1 \\
\hline Occ_Ind_R & Share with related occupation and industry experience & 0.161 & 0.165 & 0 & 1 \\
\hline Occ_Ind_U & Share with unrelated occupation and industry experience & 0.149 & 0.177 & 0 & 1 \\
\hline \multicolumn{6}{|l|}{ Control variables } \\
\hline K (000) & Capital & $29,533.66$ & $1,137,329$ & 0 & $1.80 \mathrm{E}+08$ \\
\hline L & Labor-plant size & 20.859 & 57.582 & 3 & 3331 \\
\hline FRACT_Edu & 1- the Herfindahl index of the diversity of education tracks & 0.578 & 0.215 & 0 & 0.91 \\
\hline Edu & Share with at least a 3-year university degree & 0.352 & 0.296 & 0 & 1 \\
\hline Change_LA & Share who have worked in another labor market & 0.221 & 0.221 & 0 & 1 \\
\hline Age & Years of operation & 12.577 & 8.17 & 1 & 30 \\
\hline Multiplant & Dummy $=1$ if the firm has more than 1 plants & 0.297 & 0.457 & 0 & 1 \\
\hline Den & Population per square kilometer & 1575.774 & 1943.169 & 0.2 & 5496.4 \\
\hline
\end{tabular}

All independent variables are measured at time t, besides the diversity and relatedness which are measured in $\mathrm{t}-1$, to allow time for the knowledge spillovers to take place. All monetary values are in SEK

market ${ }^{10}$ is included. Last, I include population density in the municipality to account for the importance of agglomeration economies on labor productivity and wages (Wixe 2015; Glaeser and Mare 2001). Table 11 in the appendix presents the correlation matrix. No large values are shown from there, indicating that multicollinearity is not a problem in this dataset. ${ }^{11}$ Table 2 presents the list of variables used in the estimations.

The last columns of Table 2 present the descriptive statistics, when the variables are in their non-logged form. The fractionalization indices show that individuals have rather broad backgrounds. The diversity of occupational experience is on average higher than the industrial one. On average about one third of the employees have a higher education. The table also shows that there are many small workplaces where the mean size is 21 , but the median size is 9 . Small workplaces are not uncommon for creative industries as shown in Fig. 1 above. 30 percent of the workplaces belong to multi-plant firms.

\footnotetext{
${ }^{10}$ Sweden has 81 labor market regions which consist of several municipalities. ${ }^{11}$ Multicollinearity is also tested through the VIF value in the regressions and the VIF values are very low, indicating that multicollinearity is not an issue.
}

\section{Empirical findings and analysis}

Table 3 presents the baseline results. In columns 1(a)(c) the linear regression results are presented when the dependent variable is average labor productivity. The Olley-Pakes estimations are presented in columns 2(a)(c). The last columns, 3(a)-(c) present linear regression models when average wages are instead used as dependent variables.

Starting with the diversity variables, measured through the fractionalization indices (columns 1(a), 2(a), 3(a)), results show that the diversity of previous occupation experience between employees is positively related to average labor productivity, as well as wages, the year later. However, the fractionalization index of industrial experience does not display a significant relationship for labor productivity, but it shows a negative and significant relation in the OP estimation as well as for wages. These results indicate that having people with different occupational backgrounds work together is positive for productivity while having individuals who come from many different industries is not. The findings about occupations are in line with Parrotta et al. (2014b) and Söllner (2010), but their outcome is innovation and not productivity. Regarding the industrial experience, one can speculate that the results might be driven by the 
Table 3 Baseline results

\begin{tabular}{|c|c|c|c|c|c|c|c|c|c|}
\hline & \multicolumn{3}{|c|}{ Value added - FE } & \multicolumn{3}{|c|}{ Value added - OP } & \multicolumn{3}{|l|}{ Wages - FE } \\
\hline & $1(a)$ & $1(b)$ & $1(c)$ & 2(a) & $2(b)$ & $2(c)$ & $3(a)$ & $3(b)$ & $3(c)$ \\
\hline \multirow[t]{2}{*}{ FRACT_occu } & $0.063^{* * *}$ & & & $0.038^{* *}$ & & & $0.021^{* * *}$ & & \\
\hline & $(0.009)$ & & & $(0.016)$ & & & $(0.005)$ & & \\
\hline \multirow[t]{2}{*}{ FRACT_ind } & 0.007 & & & $-0.174^{* * *}$ & & & $-0.025^{* * *}$ & & \\
\hline & $(0.008)$ & & & $(0.016)$ & & & $(0.004)$ & & \\
\hline \multirow[t]{2}{*}{ Occ_R } & & $0.026^{* * *}$ & & & $0.042^{* * *}$ & & & $0.024^{* * *}$ & \\
\hline & & $(0.008)$ & & & $(0.014)$ & & & $(0.004)$ & \\
\hline \multirow[t]{2}{*}{ Occ_U } & & -0.010 & & & $-0.184^{* * *}$ & & & $-0.016^{* * *}$ & \\
\hline & & $(0.009)$ & & & $(0.015)$ & & & $(0.004)$ & \\
\hline \multirow[t]{2}{*}{ Ind_R } & & $0.014^{*}$ & & & -0.010 & & & -0.003 & \\
\hline & & $(0.008)$ & & & $(0.014)$ & & & $(0.004)$ & \\
\hline \multirow[t]{2}{*}{ Ind_U } & & $-0.022^{* * *}$ & & & $-0.235^{* * *}$ & & & $-0.036^{* * *}$ & \\
\hline & & $(0.008)$ & & & $(0.014)$ & & & $(0.004)$ & \\
\hline \multirow[t]{2}{*}{ Occ_l } & & & $0.031^{* * *}$ & & & $0.126^{* * *}$ & & & $0.027^{* * *}$ \\
\hline & & & $(0.009)$ & & & $(0.018)$ & & & $(0.005)$ \\
\hline \multirow[t]{2}{*}{ Occ_Ind_U } & & & $-0.035^{* * *}$ & & & $-0.296^{* * *}$ & & & $-0.040^{* * *}$ \\
\hline & & & $(0.009)$ & & & $(0.016)$ & & & $(0.005)$ \\
\hline \multirow[t]{2}{*}{ Capital } & $0.021^{* * *}$ & $0.021^{* * *}$ & $0.021^{* * *}$ & $0.020^{* * *}$ & $0.022^{* * *}$ & $0.021^{* * *}$ & $0.004^{* * *}$ & $0.004^{* * *}$ & $0.004^{* * *}$ \\
\hline & $(0.002)$ & $(0.002)$ & $(0.002)$ & $(0.005)$ & $(0.005)$ & $(0.005)$ & $(0.000)$ & $(0.000)$ & $(0.000)$ \\
\hline \multirow[t]{2}{*}{ Labor } & $-0.077^{* * *}$ & $-0.072^{* * *}$ & $-0.072^{* * *}$ & $-0.060^{* * *}$ & $-0.073^{* * *}$ & $-0.076^{* * *}$ & $-0.022^{* * *}$ & $-0.022^{* * *}$ & $-0.022^{* * *}$ \\
\hline & $(0.003)$ & $(0.003)$ & $(0.003)$ & $(0.006)$ & $(0.006)$ & $(0.006)$ & $(0.002)$ & $(0.002)$ & $(0.002)$ \\
\hline \multirow[t]{2}{*}{ FRACT_Edu } & $0.079^{* * *}$ & $0.097^{* * *}$ & $0.097^{* * *}$ & $-0.073^{* * *}$ & -0.021 & $-0.057^{* * *}$ & $0.026^{* * *}$ & $0.032^{* * *}$ & $0.029^{* * *}$ \\
\hline & $(0.011)$ & $(0.011)$ & $(0.011)$ & $(0.018)$ & $(0.017)$ & $(0.017)$ & $(0.006)$ & $(0.005)$ & $(0.005)$ \\
\hline \multirow[t]{2}{*}{ Edu } & $0.044^{* * *}$ & $0.050^{* * *}$ & $0.049^{* * *}$ & $0.191^{* * *}$ & $0.181^{* * *}$ & $0.188^{* * *}$ & $0.045^{* * *}$ & $0.047^{* * *}$ & $0.045^{* * *}$ \\
\hline & $(0.011)$ & $(0.011)$ & $(0.011)$ & $(0.014)$ & $(0.013)$ & $(0.014)$ & $(0.006)$ & $(0.006)$ & $(0.006)$ \\
\hline \multirow[t]{2}{*}{ Age } & $0.002^{* * *}$ & $0.002^{* * *}$ & $0.002^{* * *}$ & -0.005 & -0.004 & -0.004 & $0.001^{* * *}$ & $0.001^{* * *}$ & $0.001^{* * *}$ \\
\hline & $(0.000)$ & $(0.000)$ & $(0.000)$ & $(0.197)$ & $(0.191)$ & $(0.189)$ & $(0.000)$ & $(0.000)$ & $(0.000)$ \\
\hline \multirow[t]{2}{*}{ Multiplant } & $0.036^{* *}$ & $0.035^{* *}$ & $0.035^{* *}$ & $0.169^{* * *}$ & $0.146^{* * *}$ & $0.159^{* * *}$ & 0.005 & 0.005 & 0.005 \\
\hline & $(0.015)$ & $(0.015)$ & $(0.015)$ & $(0.009)$ & $(0.009)$ & $(0.009)$ & $(0.004)$ & $(0.004)$ & $(0.004)$ \\
\hline \multirow[t]{2}{*}{ Change_LA } & $-0.088^{* * *}$ & $-0.083^{* * *}$ & $-0.084^{* * *}$ & $-0.036^{* *}$ & -0.020 & $-0.059 * * *$ & $-0.050^{* * *}$ & $-0.048^{* * *}$ & $-0.051^{* * *}$ \\
\hline & $(0.009)$ & $(0.009)$ & $(0.008)$ & $(0.015)$ & $(0.015)$ & $(0.015)$ & $(0.004)$ & $(0.004)$ & $(0.004)$ \\
\hline \multirow[t]{2}{*}{ Den } & $0.028^{* * *}$ & $0.027^{* * *}$ & $0.027^{* * *}$ & $0.051^{* * *}$ & $0.045^{* * *}$ & $0.047^{* * *}$ & $0.022^{* * *}$ & $0.022^{* * *}$ & $0.022^{* * *}$ \\
\hline & $(0.001)$ & $(0.001)$ & $(0.001)$ & $(0.005)$ & $(0.005)$ & $(0.005)$ & $(0.001)$ & $(0.001)$ & $(0.001)$ \\
\hline Obs. & 88,078 & 88,078 & 88,078 & 88,078 & 88,078 & 88,078 & 88,078 & 88,078 & 88,078 \\
\hline Plants & 15,983 & 15,983 & 15,983 & 15,983 & 15,983 & 15,983 & 15,983 & 15,983 & 15,983 \\
\hline R-squared & 0.785 & 0.785 & 0.785 & & & & 0.894 & 0.894 & 0.894 \\
\hline Year FE & $\checkmark$ & $\checkmark$ & $\checkmark$ & $\checkmark$ & $\checkmark$ & $\checkmark$ & $\checkmark$ & $\checkmark$ & $\checkmark$ \\
\hline
\end{tabular}

Robust standard errors in parentheses for columns 1 and 3. For the OP estimations, bootstrapped standard errors are presented with 250 replications. ${ }^{* * *} \mathrm{p}<0.01,{ }^{* *}$ $p<0.05,{ }^{*}<0.1$. Estimates of the constant term is not reported

non-transferability of industry human capital. Having individuals with different backgrounds working together can come with difficulties in communicating due to for example different routines they are used to. However, this can also have to do with the nature of creative industries where the main focus is put on the creativity of individuals which is more connected to the occupational tasks rather than the industry specific ones.
Given the differences in the results for diversity, it is interesting to see whether the results differ for the degree of diversity (columns 1(b), 2(b), 3(b)). Previous findings are inconsistent because these skills are obtained through different mechanisms and measure different types of knowledge. Results show that the relatedness of occupational experience is positively related to labor productivity and wages, but the relatedness of industry experience is statistically insignificant (besides in column 1(b) at a 
$10 \%$ significance level). The importance of related occupational experience is also supported by Östbring et al. (2017). However, the negative sign regarding industrial relatedness does not support the positive results found by Östbring et al. (2018) for KIBS industries. Unrelatedness of both industry and occupational experience are negatively related to firm performance. These results suggest that the positive sign of the fractionalization index on the diversity of occupational experience is most likely driven by the related occupational diversity rather than the unrelated one. The negative sign for the relation observed with the unrelated experience, for occupations and industry experience, is not surprising given the importance of cognitive proximity (Nooteboom 2000). If the skills are too different, no knowledge spillovers would be possible.

In the last columns for the three specifications, I now estimate the relationship between the relatedness and unrelatedness of previous experience measured through the combination of occupation and industry experience. While, to my knowledge, this has not been previously estimated in the firm relatedness literature, a branch of labor economics argues that the skills of the individuals come from the tasks they perform which is connected to both industry and occupation. Results, once more, show that the relatedness of experience is positively related to productivity and wages, but the unrelatedness of experience is negatively related to the firm performance. The fact that the magnitude of the coefficients is also much higher than in columns 1(b), 2(b), and 3(b), hints towards the idea that a combination of skills obtained from industry and occupation is specifically important for knowledge spillovers which are then mirrored in higher productivity or higher wages. Unrelatedness of experience, in this case, is negatively related to the outcomes.

The results hint towards the idea that the diversity of occupational experience is important for labor productivity, but the diversity of industrial experience shows no significance. When separating between the type of diversity, the positive results seem to be solely driven from the relatedness of previous occupational experience. These results are in general in line with the existing literature on knowledge flows and relatedness (Boschma et al. 2009; Östbring and Lindgren 2013; Östbring et al. 2017, 2018). Unrelatedness of industry and occupation experience shows an either insignificant or negative relationship to productivity and wages. ${ }^{12}$

The question that could arise is why firms would build a workforce with unrelated work experience. One reason

\footnotetext{
12 Table 11 in the appendix shows the Akaike Information Criterion (AIC) for different model specifications to ensure that the inclusion of the diversity and relatedness variables improve the model fit. As shown in the table, the inclusion of the variables decreases the AIC value, indicating indeed that the fit of
}

can be that the firms do not always have control over the diversity of the workforce (Parrotta et al. 2014a). This would especially be true in Sweden, where firms are increasingly experiencing difficulties to find the right person for the right job. This problem of job matching is even more pronounced in knowledge intensive sectors. Another reason can be that even is some skill combinations are unrelated, they might be complementary to each other, which can also matter for productivity and wages, as shown by Neffke (2017). Moreover, firms might not have full information on the type of skill mixture would create the highest productivity. Given that creative industries are characterized by mostly smaller plants, this assumption would not be unrealistic.

However, it can also be the case that the composition of the workforce within a plant is endogenous. One issue that could be problematic when looking at firm productivity, is the endogeneity of hiring where the more productive firms would hire the more productive workers. If the diversity of previous experience is endogenously chosen by the firm to enhance productivity, the regressions presented in Table 3 should be analysed with caution. A common way to deal with this issue is through the use of instrumental variables (IV). However, after trying a few different IVs, they showed to be weak ones. Given that weak instruments are biased and uninformative (Young 2019), they were not included in the paper. It is important to point out that even if there would be endogeneity in hiring, relying on economic theory and previous literature, the direction of the relationship should be going the direction tested in the paper. Diversity is important for the creation of new ideas, and the results shown for relatedness support the existing research they are based upon.

Moving on to the control variables, the diversity of educational experience is positive and significant in the linear specifications, supporting the existing research (Østergaard et al. 2011; Parrotta et al. 2014b, a). However, the OP estimation shows a negative and significant relationship between education diversity and productivity. Thus, the interpretation of that results should be with care. The rest of the control variables take the expected signs. Note that the negative sign taken by the plant size comes because the dependent variables are divided with labor (as shown in Eqs. 4-6 above). Labor elasticity is about 0.93 in all estimations, which is relatively large compared to the norm in the production function literature. This can however be driven by the that that creative

\footnotetext{
Footnote 12 (continued)

the model improves. This is further suggestive evidence regarding the importance of workforce diversity for labor productivity.
} 
industries are heavily dependent on labor as an input and much less on capital (with an elasticity of about 0.02 ). Capital is positive and significant to firm performance. The share of highly educated and workplace age are positively related to labor productivity and wages. Multiplant firms and older firms which show higher labor productivity. However, hiring individuals who have worked in other regions negatively relates to productivity. This can have to do with knowledge being rather localized and people working in different regions follow different routines and other ways of solving problems. It can also be the case that there is a need for an adjustment period which is not considered since this variable is measured at time $t$. Regarding the regional variables, as expected, the workplaces located in denser regions, are also the one showing higher productivity (Wixe 2015).

These results have broader implications for policy when it comes to workforce building for creative industries. Rather than focusing on the skills of one individual, it is important to look at how well it matches the skill sets of the people currently employed in the firm. A higher degree of relatedness is positive for labor productivity (no matter if it is measured through value added or wages), which is crucial for firm growth. These results are of great importance in countries like Sweden where knowledge-intensive firms are constantly struggling to find the right person for the right job. Given that most firms hire from the local labor market region, results suggest that when deciding on the plant location it might be of importance to study the composition of skills in the labor market as well.

\section{Robustness and stability}

To further check the stability of the results, three different sets of specifications are shown and discussed. ${ }^{13}$

\subsection{Diversity of experience or churn of employees?}

Labor mobility in creative industries is generally high (Florida 2002; Frederiksen and Sedita 2011). It is therefore important to ensure that the relationship found between diversity of experiences and productivity is not only driven by the hiring and firing behavior of the firm. Two different estimations are shown to ensure that this is indeed the case. First, Table 4 below shows the results when share of new hires as well as the share of people who have left the firm are included as control variables.

Even when the churn of the employees if controlled for, the diversity and relatedness variables behave similarly

\footnotetext{
${ }^{13}$ To ensure that changes in occupational codes in 2014 are not driving the results, one more robustness test is shown in Table 12 in the appendix. The model is now estimated for the period 2007-2014. Results are in line with what has been presented earlier in the paper.
}

to the baseline model. Diversity of occupation is however only significant in the first estimation (column $1(\mathrm{a})$ ). Occupational relatedness is positive for productivity while unrelatedness is negative. On the other hand, industry relatedness shows a positive relation to value added in the OP estimation but a negative in the wages model. As in Table 3, unrelatedness of industry experiences is negatively related to productivity. The last columns in the three estimations (1(c), 2(c), 3(c)) confirm the relationship found above. Interestingly, the share of new employees is negative for both productivity and wages. This means that for the positive spillovers to emerge from the churning of employees, more time is needed. Other research also suggests that teams become more productive the longer they work together (Bercovitz and Feldman 2011). ${ }^{14}$

Moreover, the estimations are also run on a subset of plants that do not experience any change in the workforce during the time they are in the sample. While there might be a selection of firms that satisfy this condition, this exercise is still useful for us to understand the underlying mechanisms behind labor productivity. Results are presented in Table 13 in the appendix and they show a slightly different picture where the diversity measures show a negative relationship to labor productivity. The relatedness measures for industry or occupation are now statistically insignificant in all estimations, while their unrelatedness is still negatively related to productivity. However, a higher share of related and industry experience is positively related to labor productivity, which is in line with the previous results. Similarly, unrelatedness of industry and occupation is negatively related to productivity. What this table shows is that the positive results of relatedness of industry or occupation experience might be partly driven by the churn in the labor force, where new related knowledge is crucial for the productivity boost of employees. However, even if there are no changes in the employees, they still benefit from the relatedness of experience in both industry and occupation.

\subsection{Plant size}

To see if there are any differences between the smaller and larger workplaces, the sample is separated between the ones that employ at least 10 employees and the ones that employ less than 10 employees. Note that previous literature literature drops firms with less than 5

\footnotetext{
${ }^{14}$ This is also confirmed when controlling for how long employees have worked together. The results on the main variables of interest are unchanged, and therefore that analysis is not included in the paper. The results when controlling for how long the employees have worked together are available upon request.
} 
Table 4 Productivity estimations when controlling for new hires and those who have left the firm

\begin{tabular}{|c|c|c|c|c|c|c|c|c|c|}
\hline & \multicolumn{3}{|c|}{ Value added - FE } & \multicolumn{3}{|c|}{ Value added - OP } & \multicolumn{3}{|l|}{ Wages - FE } \\
\hline & $1(a)$ & $1(b)$ & $1(c)$ & $2(a)$ & $2(b)$ & 2(c) & $3(a)$ & $3(b)$ & $3(c)$ \\
\hline \multirow[t]{2}{*}{ FRACT_oCCu } & $0.031^{* * *}$ & & & 0.024 & & & 0.004 & & \\
\hline & $(0.009)$ & & & $(0.016)$ & & & $(0.004)$ & & \\
\hline \multirow[t]{2}{*}{ FRACT_ind } & $-0.028^{* * *}$ & & & $-0.121^{* * *}$ & & & $-0.044^{* * *}$ & & \\
\hline & $(0.008)$ & & & $(0.015)$ & & & $(0.004)$ & & \\
\hline \multirow[t]{2}{*}{ Occ_R } & & $0.021^{* * *}$ & & & $0.050^{* * *}$ & & & $0.022^{* * *}$ & \\
\hline & & $(0.008)$ & & & $(0.014)$ & & & $(0.004)$ & \\
\hline \multirow[t]{2}{*}{ Occ_U } & & $-0.016^{*}$ & & & $-0.166^{* * *}$ & & & $-0.019^{* * *}$ & \\
\hline & & $(0.009)$ & & & $(0.015)$ & & & $(0.004)$ & \\
\hline \multirow[t]{2}{*}{ Ind_R } & & -0.004 & & & $0.028^{* *}$ & & & $-0.013^{* * *}$ & \\
\hline & & $(0.008)$ & & & $(0.014)$ & & & $(0.004)$ & \\
\hline \multirow[t]{2}{*}{ Ind_U } & & $-0.044^{* * *}$ & & & $-0.182^{* * *}$ & & & $-0.047^{* * *}$ & \\
\hline & & $(0.007)$ & & & $(0.014)$ & & & $(0.004)$ & \\
\hline \multirow[t]{2}{*}{ Occ_Ind_R } & & & $0.019^{* *}$ & & & $0.151^{* * *}$ & & & $0.021^{* * *}$ \\
\hline & & & $(0.009)$ & & & $(0.017)$ & & & $(0.005)$ \\
\hline \multirow[t]{2}{*}{ Occ_Ind_U } & & & $-0.053^{* * *}$ & & & $-0.246^{* * *}$ & & & $-0.049^{* * *}$ \\
\hline & & & $(0.009)$ & & & $(0.015)$ & & & $(0.004)$ \\
\hline \multirow[t]{2}{*}{ Share hires } & $-0.356^{* * *}$ & $-0.359^{* * *}$ & $-0.357^{* * *}$ & $-0.576^{* * *}$ & $-0.544^{* * *}$ & $-0.572^{* * *}$ & $-0.192^{* * *}$ & $-0.189^{* * *}$ & $-0.187^{* * *}$ \\
\hline & $(0.009)$ & $(0.009)$ & $(0.009)$ & $(0.015)$ & $(0.015)$ & $(0.015)$ & $(0.004)$ & $(0.004)$ & $(0.004)$ \\
\hline \multirow[t]{2}{*}{ Share left } & $0.017^{*}$ & $0.018^{*}$ & $0.017^{*}$ & $0.066^{* * *}$ & $0.054^{* * *}$ & $0.056^{* * *}$ & $0.013^{* * *}$ & $0.013^{* * *}$ & $0.012^{* * *}$ \\
\hline & (0.010) & $(0.010)$ & $(0.010)$ & $(0.016)$ & $(0.016)$ & $(0.016)$ & $(0.004)$ & $(0.004)$ & $(0.004)$ \\
\hline Observations & 88,078 & 88,078 & 88,078 & 88,078 & 88,078 & 88,078 & 88,078 & 88,078 & 88,078 \\
\hline Plants & 15,983 & 15,983 & 15,983 & 15,983 & 15,983 & 15,983 & 15,983 & 15,983 & 15,983 \\
\hline R-squared & 0.791 & 0.791 & 0.791 & & & & 0.898 & 0.898 & 0.898 \\
\hline
\end{tabular}

Robust standard errors in parentheses for columns 1 and 3 . For the OP estimations, bootstrapped standard errors are presented with 250 replications. ${ }^{* * *} \mathrm{p}<0.01$, ${ }^{* *} \mathrm{p}<0.05,{ }^{*}<0.1$. The constant term is not reported. Control variables and year fixed effects are included in all estimations

employees (Östbring et al., 2018) or 10 employees (Parrotta et al., 2014a, 2014b). The results are presented in Table 5 below.

They are mostly in line with what has been shown before for the larger firms. The main difference is that smaller plants do not seem benefit from the relatedness of occupations or industries, but rather from the relatedness of industry and occupation relatedness. Unrelatedness is however still negatively related to productivity. There can be two different explanations to why we do not observe significant results for the relatedness of occupations. Small firms might not reach as high levels of relatedness as the larger firms, and there too little variation in the variable to show significant results. It can be the case that due to the low number of workers people in the plant need to work with different tasks simultaneously and work all together rather than to be separated into teams. It can also be that firms need to reach a specific size to benefit from relatedness. However, the relatedness of both industry and occupation experience is significant for both categories.

\subsection{Plant age}

Following Timmermans and Boschma (2014), Table 6 presents the results for plants which are at least 5 years old, since the younger firms suffer from the liability of newness (Stinchcombe 1965). In the sample, approximately $26 \%$ of the plants are now dropped.

Results are in line with the baseline estimation and show that the diversity of occupational experience is positively related to labor productivity, but the diversity of industry experience is not. When looking at relatedness, the relatedness of occupations, the relatedness of industry experience, as well as the relatedness in their combination are positive for labor productivity. However, industry relatedness shows no significance on the wage estimation. On the other hand, the unrelatedness of both industry and occupation experience are negatively related to firm performance. This suggests the importance of cognitive proximity among workers, when it comes to knowledge spillovers and productivity advantages.

Related to this issue, to understand what facilitates the success of new firms in creative industries, Table 7 presents the results for start-ups instead of the older firms. 
Table 5 Results with plants when a cutoff of 10 employees is made

\begin{tabular}{|c|c|c|c|c|c|c|c|c|c|}
\hline & \multicolumn{3}{|c|}{ Average value added $-\mathrm{FE}$} & \multicolumn{3}{|c|}{ Average value added - OP } & \multicolumn{3}{|c|}{ Average Wages - FE } \\
\hline & $1(a)$ & $1(b)$ & $1(c)$ & $2(a)$ & $2(b)$ & $2(c)$ & $3(a)$ & $3(b)$ & $3(c)$ \\
\hline \multicolumn{10}{|c|}{ More than 10 employees } \\
\hline \multirow[t]{2}{*}{ FRACT_occu } & $0.063^{* * *}$ & & & 0.042 & & & $0.021^{* * *}$ & & \\
\hline & $(0.016)$ & & & $(0.031)$ & & & $(0.007)$ & & \\
\hline \multirow[t]{2}{*}{ FRACT_ind } & -0.019 & & & $-0.263^{* * *}$ & & & $-0.041^{* * *}$ & & \\
\hline & $(0.013)$ & & & $(0.024)$ & & & $(0.005)$ & & \\
\hline \multirow[t]{2}{*}{ Occ_R } & & $0.073^{* * *}$ & & & $0.173^{* * *}$ & & & $0.052^{* * *}$ & \\
\hline & & $(0.017)$ & & & $(0.031)$ & & & $(0.008)$ & \\
\hline \multirow[t]{2}{*}{ Occ_U } & & -0.019 & & & $-0.193^{* * *}$ & & & $-0.036^{* * *}$ & \\
\hline & & $(0.019)$ & & & $(0.033)$ & & & $(0.008)$ & \\
\hline \multirow[t]{2}{*}{ Ind_R } & & 0.017 & & & -0.026 & & & -0.001 & \\
\hline & & $(0.014)$ & & & $(0.025)$ & & & $(0.006)$ & \\
\hline \multirow[t]{2}{*}{ Ind_U } & & $-0.057^{* * *}$ & & & $-0.410^{* * *}$ & & & $-0.068^{* * *}$ & \\
\hline & & $(0.015)$ & & & $(0.028)$ & & & $(0.006)$ & \\
\hline \multirow[t]{2}{*}{ Occ_Ind_R } & & & $0.051^{* * *}$ & & & $0.180^{* * *}$ & & & $0.050^{* * *}$ \\
\hline & & & $(0.018)$ & & & $(0.033)$ & & & $(0.008)$ \\
\hline \multirow[t]{2}{*}{ Occ_Ind_U } & & & $-0.090^{* * *}$ & & & $-0.582^{* * *}$ & & & $-0.088^{* * *}$ \\
\hline & & & $(0.019)$ & & & $(0.038)$ & & & $(0.008)$ \\
\hline Observations & 31,769 & 31,769 & 31,769 & 31,769 & 31,769 & 31,769 & 31,769 & 31,769 & 31,769 \\
\hline Plants & 7579 & 7579 & 7579 & 7579 & 7579 & 7579 & 7579 & 7579 & 7579 \\
\hline R-squared & 0.798 & 0.799 & 0.798 & & & & 0.914 & 0.915 & 0.914 \\
\hline \multicolumn{10}{|c|}{ Less than 10 employees } \\
\hline \multirow[t]{2}{*}{ FRACT_occu } & $0.042^{* * *}$ & & & 0.019 & & & $0.019^{* * *}$ & & \\
\hline & $(0.014)$ & & & $(0.023)$ & & & $(0.007)$ & & \\
\hline \multirow[t]{2}{*}{ FRACT_ind } & $0.047^{* * *}$ & & & $-0.167^{* * *}$ & & & $0.011^{*}$ & & \\
\hline & $(0.013)$ & & & $(0.022)$ & & & $(0.006)$ & & \\
\hline \multirow[t]{2}{*}{ Occ_R } & & -0.001 & & & 0.016 & & & $0.011^{*}$ & \\
\hline & & $(0.011)$ & & & $(0.019)$ & & & $(0.006)$ & \\
\hline \multirow[t]{2}{*}{ Occ_U } & & $-0.028^{* *}$ & & & $-0.155^{* * *}$ & & & $-0.013^{* *}$ & \\
\hline & & $(0.012)$ & & & $(0.018)$ & & & $(0.007)$ & \\
\hline \multirow[t]{2}{*}{ Ind_R } & & $0.036^{* * *}$ & & & -0.028 & & & $0.014^{* *}$ & \\
\hline & & $(0.012)$ & & & $(0.021)$ & & & $(0.006)$ & \\
\hline \multirow[t]{2}{*}{ Ind_U } & & 0.006 & & & $-0.192^{* * *}$ & & & -0.005 & \\
\hline & & $(0.011)$ & & & $(0.017)$ & & & $(0.006)$ & \\
\hline \multirow[t]{2}{*}{ Occ_Ind_R } & & & $0.040^{* * *}$ & & & $0.085^{* * *}$ & & & $0.025^{* * *}$ \\
\hline & & & $(0.013)$ & & & $(0.023)$ & & & $(0.007)$ \\
\hline \multirow[t]{2}{*}{ Occ_Ind_U } & & & -0.018 & & & $-0.217^{* * *}$ & & & $-0.014^{* *}$ \\
\hline & & & $(0.014)$ & & & $(0.019)$ & & & $(0.007)$ \\
\hline Observations & 37,430 & 37,430 & 37,430 & 37,430 & 37,430 & 37,430 & 37,430 & 37,430 & 37,430 \\
\hline Plants & 7979 & 7979 & 7979 & 7979 & 7979 & 7979 & 7979 & 7979 & 7979 \\
\hline R-squared & 0.797 & 0.797 & 0.797 & & & & 0.895 & 0.895 & 0.895 \\
\hline
\end{tabular}

Robust standard errors in parentheses for columns 1 and 3 . For the OP estimations, bootstrapped standard errors are presented with 250 replications. ${ }^{* * *} \mathrm{p}<0.01,{ }^{* *}$ $\mathrm{p}<0.05,{ }^{*}<0.1$. The constant term is not reported. Control variables and year fixed effects are included in all estimations

Results here are not as clear cut, but rather similar to the results shown for the smaller plants in Table 6 above. While the diversity of occupation continues to show a positive relationship, the results for industry diversity are not stable where the fixed effect estimations for value added show a positive sign but the other estimations (columns 2(a) and 3(a)) instead display a negative relationship. Moreover, the relatedness measures are mainly statistically insignificant or do not show consistent results across the estimations when taken separately. 
Table 6 Regression results when only firms that are at least 5 years old are included

\begin{tabular}{|c|c|c|c|c|c|c|c|c|c|}
\hline & \multicolumn{3}{|c|}{ Value added - FE } & \multicolumn{3}{|c|}{ Value added - OP } & \multicolumn{3}{|l|}{ Wages - FE } \\
\hline & $1(a)$ & $1(b)$ & $1(c)$ & $2(a)$ & $2(b)$ & $2(c)$ & $3(a)$ & $3(b)$ & $3(c)$ \\
\hline \multirow[t]{2}{*}{ FRACT_occu } & $0.069^{* * *}$ & & & $0.051^{* *}$ & & & $0.026^{* * *}$ & & \\
\hline & $(0.010)$ & & & $(0.020)$ & & & $(0.005)$ & & \\
\hline \multirow[t]{2}{*}{ FRACT_ind } & 0.010 & & & $-0.107^{* * *}$ & & & $-0.022^{* * *}$ & & \\
\hline & $(0.009)$ & & & $(0.017)$ & & & $(0.004)$ & & \\
\hline \multirow[t]{2}{*}{ Occ_R } & & $0.041^{* * *}$ & & & $0.081^{* * *}$ & & & $0.031^{* * *}$ & \\
\hline & & $(0.009)$ & & & $(0.018)$ & & & $(0.005)$ & \\
\hline \multirow[t]{2}{*}{ Occ_U } & & -0.001 & & & $-0.174^{* * *}$ & & & $-0.010^{*}$ & \\
\hline & & $(0.011)$ & & & $(0.019)$ & & & $(0.005)$ & \\
\hline \multirow[t]{2}{*}{ Ind_R } & & $0.025^{* * *}$ & & & $0.041^{* *}$ & & & 0.002 & \\
\hline & & $(0.009)$ & & & $(0.018)$ & & & $(0.004)$ & \\
\hline \multirow[t]{2}{*}{ Ind_U } & & -0.014 & & & $-0.178^{* * *}$ & & & $-0.031^{* * *}$ & \\
\hline & & $(0.009)$ & & & $(0.016)$ & & & $(0.004)$ & \\
\hline \multirow[t]{2}{*}{ Occ_Ind_R } & & & $0.042^{* * *}$ & & & $0.191^{* * *}$ & & & $0.031^{* * *}$ \\
\hline & & & $(0.011)$ & & & $(0.021)$ & & & $(0.005)$ \\
\hline \multirow[t]{2}{*}{ Occ_Ind_U } & & & $-0.040^{* * *}$ & & & $-0.267^{* * *}$ & & & $-0.039^{* * *}$ \\
\hline & & & $(0.012)$ & & & $(0.019)$ & & & $(0.005)$ \\
\hline Observations & 65,424 & 65,424 & 65,424 & 65,424 & 65,424 & 65,424 & 65,424 & 65,424 & 65,424 \\
\hline Plants & 12,020 & 12,020 & 12,020 & 12,020 & 12,020 & 12,020 & 12,020 & 12,020 & 12,020 \\
\hline R-squared & 0.780 & 0.780 & 0.780 & & & & 0.899 & 0.899 & 0.899 \\
\hline
\end{tabular}

Robust standard errors in parentheses for columns 1 and 3. For the OP estimations, bootstrapped standard errors are presented with 250 replications. ${ }^{* * *} \mathrm{p}<0.01,{ }^{* *}$ $\mathrm{p}<0.05,{ }^{*}<0.1$. The constant term is not reported. Control variables and year fixed effects are included in all estimations

Table 7 Labor productivity in startups

\begin{tabular}{|c|c|c|c|c|c|c|c|c|c|}
\hline & \multicolumn{3}{|c|}{ Value added - FE } & \multicolumn{3}{|c|}{ Value added - OP } & \multicolumn{3}{|l|}{ Wages - FE } \\
\hline & $1(a)$ & $1(b)$ & $1(c)$ & $2(a)$ & $2(b)$ & $2(c)$ & $3(a)$ & $3(b)$ & $3(c)$ \\
\hline \multirow[t]{2}{*}{ FRACT_occu } & $0.092^{* * *}$ & & & $0.066^{* *}$ & & & $0.025^{* * *}$ & & \\
\hline & $(0.016)$ & & & $(0.028)$ & & & $(0.008)$ & & \\
\hline \multirow[t]{2}{*}{ FRACT_ind } & $0.032^{* *}$ & & & $-0.239^{* * *}$ & & & $-0.024^{* * *}$ & & \\
\hline & $(0.015)$ & & & $(0.027)$ & & & $(0.007)$ & & \\
\hline \multirow[t]{2}{*}{ Occ_R } & & 0.017 & & & 0.034 & & & $0.012^{*}$ & \\
\hline & & $(0.014)$ & & & $(0.024)$ & & & $(0.007)$ & \\
\hline \multirow[t]{2}{*}{ Occ_U } & & -0.003 & & & $-0.170^{* * *}$ & & & -0.009 & \\
\hline & & $(0.015)$ & & & $(0.025)$ & & & $(0.008)$ & \\
\hline \multirow[t]{2}{*}{ Ind_R } & & 0.017 & & & $-0.059^{* *}$ & & & $-0.015^{* *}$ & \\
\hline & & $(0.015)$ & & & $(0.025)$ & & & $(0.007)$ & \\
\hline \multirow[t]{2}{*}{ Ind_U } & & -0.020 & & & $-0.294^{* * *}$ & & & $-0.035^{* * *}$ & \\
\hline & & $(0.014)$ & & & $(0.024)$ & & & $(0.007)$ & \\
\hline \multirow[t]{2}{*}{ Occ_Ind_R } & & & $0.032^{* *}$ & & & $0.117^{* * *}$ & & & $0.013^{*}$ \\
\hline & & & $(0.016)$ & & & $(0.029)$ & & & $(0.008)$ \\
\hline \multirow[t]{2}{*}{ Occ_Ind_U } & & & $-0.031^{* *}$ & & & $-0.294^{* * *}$ & & & $-0.027^{* * *}$ \\
\hline & & & $(0.015)$ & & & $(0.025)$ & & & $(0.007)$ \\
\hline Observations & 32,259 & 32,259 & 32,259 & 32,259 & 32,259 & 32,259 & 32,259 & 32,259 & 32,259 \\
\hline R-squared & 0.770 & 0.770 & 0.770 & & & & 0.903 & 0.903 & 0.903 \\
\hline
\end{tabular}


When looking at the combination of industry and occupation experience results are in line with what has been previously shown in the paper; relatedness is positive for productivity but unrelatedness of experience harms the productivity growth of plants. What these results suggest is that when it comes to startups, the experience of the workers needs to be diverse, but not too diverse. Since the teams in this case are smaller, and the probability of working together is larger, the diversity of teams needs to be related both for industry and for occupation experience, at least in the first years of the startups. These results support the findings of Koster and Andersson (2018) who argue about the importance of occupational skills on top of industry skills for the survival of startups. Focusing only on one of these dimensions when examining the previous work experience is not enough to show positive results on productivity.

\section{Conclusions}

The paper studies how the diversity of work experiences among employees relates to labor productivity in creative industries in Sweden. The idea is that when changing jobs, workers bring their expertise and knowledge with them. While a large literature argues about the positive effects of labor mobility, the type of knowledge and skills that are brought into the firm is not largely studied. Some studies show however that what mostly contributes to firm performance depends on the type of knowledge that is brought in and how that matches the existing knowledge base (Boschma et al. 2009; Timmermans and Boschma 2014; Östbring et al. 2018). Others have shown the importance of knowledge diversity for innovation or productivity growth in a firm (Parrotta et al. 2014a, b). Yet, to my knowledge, no study has looked at the diversity of the previous experience of the workers, both in terms of occupations and industries, and how that relates to labor productivity.

The results of this paper show that diversity of occupational experience is positive for labor productivity, but this the diversity of industrial experience shows either insignificant or negative relationship. When the distinction between relatedness and unrelatedness of experience is made, the results indicate that the positive relationship is mostly driven by relatedness, which is in line with similar existing studies on relatedness and performance (Boschma et al. 2009; Martynovich and Henning 2018; Östbring et al. 2018). This relationship is even stronger when experience relatedness is measured as a combination of industry and occupation, rather than when they are separated. This suggests that the specific human capital of the individuals is connected to both industry and occupation.

Besides contributing to the literature regarding the micro-mechanisms of knowledge spillovers and productivity which arise from the previous experience, these results are also important from a policy perspective. Given the importance of creative industries in regional development, understanding how labor productivity is enhanced in these firms benefit the economy at large. Moreover, these results reflect the importance of finding the right person for the right job. Knowledge-intensive firms in Sweden are continuously having difficulties to find the competence for the job. The results shown here results suggest that one potential way to look for the right competence is to consider the composition of the experience of the people within the plant. Hiring people with related experience in terms of occupation or occupation and industry, would benefit the firm in the form of higher labor productivity (which is mirrored in both value added and wages). Given that most firms hire people from the region, these results could also be analyzed as suggestion for creative, knowledge intensive firms to locate in areas where there is a large pool of people with related skills to one another.

The study creates possibilities for further research. Given the importance of occupational-specific skills showed in the results, it would be interesting to dig deeper into what type of occupations are the ones that when combined productivity is enhanced. Previous literature has shown how skills should not overlap for new knowledge to be created (Uzzi et al. 2013), but the literature on occupational combinations is scarce. Moreover, it would be interesting to look at this through an innovation perspective. Third, while the purpose of this paper has been to look at diversity and relatedness, it would be insightful to expand the discussion by looking at skill complementarity and firm productivity. Skill complementarity is not captured in the diversity or relatedness measures, but it would be a great avenue to expand the current analysis. Further, as previously mentioned, the results should be analyzed with caution, given the lack of a suitable instrumental variable or any other exogenous shock, which would have made possible causal results. Moving into the direction of causality is another avenue where this work can be extended into.

\section{Appendix}

See Tables 8, 9, 10, 11, 12, 13, and 14. 
Table 8 Industries included in the analysis

\begin{tabular}{ll}
\hline NACE & Description \\
\hline 58 & Publishing activities \\
59 & Motion picture, video and television programme production, sound recording and music publishing activities \\
60 & Programming and broadcasting activities \\
62 & Computer programming, consultancy and related activities \\
71 & Architectural and engineering activities; technical testing and analysis \\
72 & Scientific research and development \\
73 & Advertising and market research \\
74 & Other professional, scientific and technical activities \\
90 & Creative, arts and entertainment activities \\
91 & Libraries, archives, museums and other cultural activities \\
93 & Sports activities and amusement and recreation activities \\
\hline
\end{tabular}

Table 9 Characteristics of the creative industries and the plants in the rest of the economy

\begin{tabular}{|c|c|c|c|c|c|c|}
\hline & \multicolumn{3}{|c|}{ Non-creative industries } & \multicolumn{3}{|c|}{ Creative industries } \\
\hline & 2007 & 2016 & Growth & 2007 & 2016 & Growth \\
\hline Employment & $3,779,542$ & $4,128,471$ & $9.2 \%$ & 361,781 & 424,406 & $17.3 \%$ \\
\hline Number of plants & 419,993 & 498,471 & $18.7 \%$ & 72,528 & 94,576 & $30.4 \%$ \\
\hline Average Wages & 2111 & 2747 & $30.1 \%$ & 2455 & 3104 & $26.4 \%$ \\
\hline Average Productivity & 5495 & 6874 & $25.1 \%$ & 5555 & 6938 & $24.9 \%$ \\
\hline Average sales & 1814 & 1937 & $6.8 \%$ & 1169 & 1288 & $10.2 \%$ \\
\hline
\end{tabular}

Table 10 The 2-digit educational types

\begin{tabular}{ll}
\hline Group & Education type \\
\hline 1 & General education \\
14 & Pedagogics and teaching \\
21 & Arts and media \\
22 & The humanities \\
31 & Social and behavioral science \\
32 & Journalism and information \\
34 & Business \\
38 & Law and legal science \\
42 & Biology and environmental science \\
44 & Physics, chemistry, and geoscience \\
46 & Mathematics and natural science \\
48 & Computer science \\
52 & Engineering: technical, mechanical, chemical, and electronics \\
54 & Engineering: manufacturing \\
58 & Engineering: construction \\
62 & Agriculture \\
64 & Animal healthcare \\
72 & Healthcare \\
76 & Social work \\
81 & Personal services \\
84 & Transport services \\
85 & Environmental care \\
86 & Security \\
\hline &
\end{tabular}




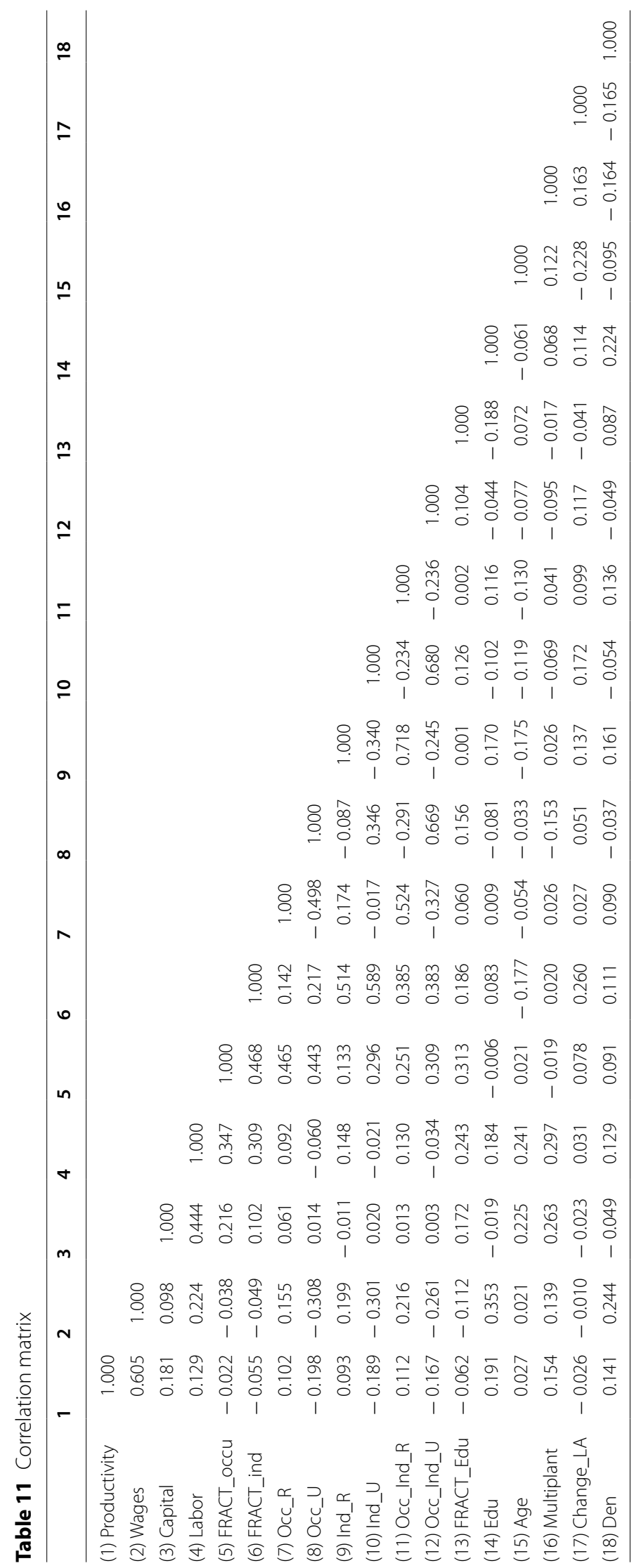


Table 12 Akaike information criteria for the different estimations

\begin{tabular}{llll}
\hline & \multicolumn{2}{c}{ Average value added } & Average wages \\
\hline K, L & 50,799 & & $-93,790$ \\
Control variables & 49,958 & & $-96,290$ \\
Full model 1(a) & & 49,796 & \\
Full model 1(b) & & 49,809 & \\
Full model 1(c) & 49,824 & $-96,408$ \\
Full model 3(a) & & $-96,733$ \\
Full model 3(b) & & $-96,564$ \\
Full model 3(c) & &
\end{tabular}

In the first columns the AIC is calculated only when including capital and labor in the estimations. In the second columns, all control variables are included besides the variables of interest. In the last three columns, the full models are estimated. 1(a)-1(c) and 3(a)-3(c) correspond to the estimations in Table 3

Table 13 Regression results when the sample ends in 2014 to ensure robustness from changes in SSYK codes

\begin{tabular}{|c|c|c|c|c|c|c|c|c|c|}
\hline \multirow{2}{*}{ FRACT_occu } & \multicolumn{3}{|c|}{ Average value added - FE } & \multicolumn{3}{|c|}{ Average value added - OP } & \multicolumn{3}{|c|}{ average wages - FE } \\
\hline & $0.073^{* * *}$ & & & $0.061^{* * *}$ & & & $0.032^{* * *}$ & & \\
\hline & $(0.011)$ & & & $(0.020)$ & & & $(0.006)$ & & \\
\hline FRACT_ind & 0.013 & & & $-0.177^{*}$ & & & -0.024 & & \\
\hline & $(0.009)$ & & & $(0.017)$ & & & $(0.004)$ & & \\
\hline \multirow[t]{2}{*}{ Occ_R } & \multicolumn{3}{|c|}{$0.030^{* * *}$} & \multicolumn{3}{|c|}{$0.052^{* * *}$} & \multicolumn{3}{|c|}{$0.031^{* * *}$} \\
\hline & \multicolumn{3}{|c|}{$(0.010)$} & \multicolumn{3}{|c|}{$(0.018)$} & \multicolumn{3}{|c|}{$(0.005)$} \\
\hline \multirow[t]{2}{*}{ Occ_U } & \multicolumn{3}{|c|}{-0.006} & \multicolumn{3}{|c|}{$-0.175^{* * *}$} & \multicolumn{3}{|c|}{-0.002} \\
\hline & \multicolumn{3}{|c|}{$(0.011)$} & \multicolumn{3}{|c|}{$(0.017)$} & \multicolumn{3}{|c|}{$(0.005)$} \\
\hline \multirow[t]{2}{*}{ Ind_R } & \multicolumn{3}{|c|}{$0.023^{* *}$} & \multicolumn{3}{|c|}{-0.004} & \multicolumn{3}{|c|}{-0.002} \\
\hline & \multicolumn{3}{|c|}{$(0.009)$} & \multicolumn{3}{|c|}{$(0.017)$} & \multicolumn{3}{|c|}{$(0.004)$} \\
\hline \multirow[t]{2}{*}{ Ind_U } & \multicolumn{3}{|c|}{$-0.016^{*}$} & \multicolumn{3}{|c|}{$-0.240^{* * *}$} & \multicolumn{3}{|c|}{$-0.035^{* * *}$} \\
\hline & & $(0.009)$ & & & $(0.015)$ & & & $(0.004)$ & \\
\hline \multirow[t]{2}{*}{ Occ_Ind_R } & & & $0.041^{* * *}$ & & & $0.135^{* * *}$ & & & $0.028^{* * *}$ \\
\hline & & & $(0.011)$ & & & $(0.020)$ & & & $(0.005)$ \\
\hline \multirow[t]{2}{*}{ Occ_Ind_Un } & & & $-0.023^{* *}$ & & & $-0.302^{* * *}$ & & & $-0.035^{* * *}$ \\
\hline & & & $(0.011)$ & & & $(0.016)$ & & & $(0.005)$ \\
\hline Observations & 66,748 & 66,748 & 66,748 & 66,748 & 66,748 & 66,748 & 66,748 & 66,748 & 66,748 \\
\hline Plants & 14,786 & 14,786 & 14,786 & 14,786 & 14,786 & 14,786 & 14,786 & 14,786 & 14,786 \\
\hline R- squared & 0.793 & 0.793 & 0.793 & & & & 0.900 & 0.900 & 0.900 \\
\hline
\end{tabular}

Robust standard errors in parentheses for columns 1 and 3 . For the OP estimations, bootstrapped standard errors are presented with 250 replications. ${ }^{* * *} \mathrm{p}<0.01$, ${ }^{* *} \mathrm{p}<0.05,{ }^{*}<0.1$. The constant term is not reported. Control variables and year fixed effects are included in all estimations 
Table 14 Labor productivity in firms that have not experienced any change in the workforce

\begin{tabular}{|c|c|c|c|c|c|c|c|c|c|}
\hline & Value add & - OLS & & Value ado & $d-O P$ & & Wages - 0 & & \\
\hline & $1(a)$ & $1(b)$ & $1(c)$ & $2(a)$ & 2 (b) & $2(c)$ & $3(a)$ & $3(b)$ & $3(c)$ \\
\hline \multirow[t]{2}{*}{ FRACT_occu } & $-0.160^{* *}$ & & & $-0.189^{*}$ & & & $-0.129^{* *}$ & & \\
\hline & $(0.063)$ & & & $(0.107)$ & & & $(0.054)$ & & \\
\hline \multirow[t]{2}{*}{ FRACT_ind } & $-0.198^{*}$ & & & -0.153 & & & $-0.147^{*}$ & & \\
\hline & $(0.104)$ & & & $(0.136)$ & & & $(0.079)$ & & \\
\hline \multirow[t]{2}{*}{ Occ_R } & & -0.033 & & & -0.069 & & & 0.031 & \\
\hline & & $(0.055)$ & & & $(0.093)$ & & & $(0.039)$ & \\
\hline \multirow[t]{2}{*}{ Occ_U } & & $-0.268^{* * *}$ & & & $-0.267^{* * *}$ & & & $-0.287^{* * *}$ & \\
\hline & & $(0.056)$ & & & $(0.091)$ & & & $(0.058)$ & \\
\hline \multirow[t]{2}{*}{ Ind_R } & & 0.038 & & & 0.100 & & & 0.077 & \\
\hline & & $(0.088)$ & & & $(0.126)$ & & & $(0.067)$ & \\
\hline \multirow[t]{2}{*}{ Ind_U } & & $-0.271^{* * *}$ & & & $-0.266^{* *}$ & & & $-0.219^{* * *}$ & \\
\hline & & (0.093) & & & $(0.121)$ & & & $(0.078)$ & \\
\hline \multirow[t]{2}{*}{ Occ_Ind_R } & & & $0.246^{* *}$ & & & $0.358^{* *}$ & & & $0.253^{* * *}$ \\
\hline & & & $(0.121)$ & & & $(0.166)$ & & & $(0.084)$ \\
\hline \multirow[t]{2}{*}{ Occ_Ind_U } & & & $-0.271^{* * *}$ & & & $-0.288^{* *}$ & & & $-0.315^{* * *}$ \\
\hline & & & (0.098) & & & $(0.134)$ & & & $(0.117)$ \\
\hline Observations & 1,175 & 1,175 & 1,175 & 1,175 & 1,175 & 1,175 & 1,175 & 1,175 & 1,175 \\
\hline R-squared & 0.275 & 0.294 & 0.274 & & & & 0.349 & 0.385 & 0.356 \\
\hline
\end{tabular}

Robust standard errors in parentheses for columns 1 and 3 . For the OP estimations, bootstrapped standard errors are presented with 250 replications. ${ }^{* *} \mathrm{p}<0.01$, ${ }^{* *} \mathrm{p}<0.05,{ }^{*}<0.1$. The constant term is not reported. Since the diversity measures are constant, the results in columns 1 and 3 do not include firm fixed effects, but instead industry, region, and year fixed effects. Control variables are included in all estimations

\section{Acknowledgements}

I want to thank the three anonymous referees, Martin Henning, Ron Boschma, Rikard Eriksson, Charlotta Mellander, Johan Klaesson, Sandy Dall'erba, Geoffrey Hewings, Jonna Rickardsson, and Emma Lappi for helpful comments and suggestions during different stages of this paper.

\section{Authors' contributions}

I am the sole author of the paper, thus responsible for the whole manuscript.

\section{Funding}

Not applicable.

\section{Availability of data and materials}

The micro-data used in this paper are protected by the Swedish Secrecy Act and cannot be freely accessed or shared. The data can however be ordered through Statistics Sweden, through the following link: https://scb.se/en/servi ces/guidance-for-researchers-and-universities/.

\section{Declarations}

\section{Ethics approval and consent to participate}

Not applicable.

\section{Consent for publication}

Not applicable.

\section{Competing interests}

The author has no competing interests to disclose.

\section{Author details}

${ }_{1}^{1}$ SOFI, Stockholm University, Stockholm, Sweden. ${ }^{2}$ Centre for Entrepreneurship and Spatial Economics (CEnSE), Jönköping International Business School, Jönköping, Sweden.
Received: 25 August 2020 Accepted: 22 June 2021

Published online: 06 July 2021

\section{References}

Alesina, A., Devleeschauwer, A., Easterly, W., Kurlat, S., Wacziarg, R.: Fractionalization. J. Econ. Growth 8(2), 155-194 (2003)

Almeida, P., Kogut, B.: Localization of knowledge and the mobility of engineers in regional networks. Manag. Sci. 45(7), 905-917 (1999)

And, H.W.A., Isaksen, A.: Knowledge intensive business services and urban industrial development. Serv. Ind. J. 27(3), 321-338 (2007)

Arcidiacono, P., Kinsler, J., Price, J.: Productivity spillovers in team production: evidence from professional basketball. J. Law Econ. 35(1), 191-225 (2017)

Autor, D.H., Levy, F., Murnane, R.J.: The skill content of recent technological change: an empirical exploration. Q. J. Econ. 118(4), 1279-1333 (2003)

Bacolod, M., Blum, B.S., Strange, W.C.: Skills in the city. J. Urban Econ. 65(2), 136-153 (2009)

Bantel, K.A., Jackson, S.E.: Top management and innovations in banking: Does the composition of the top team make a difference? Strateg. Manag. J. 10(S1), 107-124 (1989)

Barbour, E., Markusen, A.: Regional occupational and industrial structure: does one imply the other? Int. Reg. Sci. Rev. 30(1), 72-90 (2007)

Bassett-Jones, N.: The paradox of diversity management, creativity and innovation. Creat. Innov. Manag. 14(2), 169-175 (2005)

Becker, G.S.: Investment in human capital: a theoretical analysis. J. Polit. Econ. 70(5, Part 2), 9-49 (1962)

Becker, G.S.: Human Capital: A Theoretical Analysis with Special Reference to Education. Columbia University Press, New York (1964)

Bercovitz, J., Feldman, M.: The mechanisms of collaboration in inventive teams: composition, social networks, and geography. Res. Policy 40(1), 81-93 (2011)

Berliant, M., Fujita, M.:The dynamics of knowledge diversity and economic growth. South. Econ. J. 77(4), 856-884 (2011) 
Boschma, R.: Proximity and innovation: a critical assessment. Reg. Stud. 39(1), 61-74 (2005)

Boschma, R., Eriksson, R., Lindgren, U.: How does labour mobility affect the performance of plants? The importance of relatedness and geographical proximity. J. Econ. Geogr. 9(2), 169-190 (2009)

Card, D., Heining, J., Kline, P.: Workplace heterogeneity and the rise of West German wage inequality. Q. J. Econ. 128(3), 967-1015 (2013)

Castañer, X., Campos, L.: The determinants of artistic innovation: bringing in the role of organizations. J. Cult. Econ. 26(1), 29-52 (2002)

Caves, R.E.: Creative Industries: Contracts Between Art and Commerce. Harvard University Press, Cambridge (2000)

Christopherson, S.:The divergent worlds of new media: how policy shapes work in the creative economy. Rev. Policy Res. 21(4), 543-558 (2004)

Cohen, W.M., Levinthal, D.A.: Absorptive capacity: a new perspective on learning and innovation. Adm. Sci. q. 35(1), 128-152 (1990)

Delgado-Verde, M., Castro, G.-d, Amores-Salvadó, J.: Intellectual capital and radical innovation: Exploring the quadratic effects in technology-based manufacturing firms. Technovation 54, 35-47 (2016)

Essletzbichler, J.: Relatedness, Industrial Branching and Technological Cohesion in US Metropolitan Areas. Reg. Stud. 49(5), 752-766 (2015)

Florida, R.: The rise of the creative class: and how it's transforming work, leisure, and everyday life. Basic Books, New York (2002)

Florida, R., Mellander, C., Stolarick, K.: Inside the black box of regional development-human capital, the creative class and tolerance. J. Econ. Geogr. 8(5), 615-649 (2008)

Frederiksen, L., Sedita, S.R.: Embodied knowledge transfer for innovation: comparing interfirm labor mobility between music and manufacturing industries. In: Belussi, F., Staber, U. (eds.) Managing Networks of Creativity. Routledge, Abingdon (2011)

Frenken, K., Van Oort, F., Verburg, T.: Related variety, unrelated variety and regional economic growth. Reg. Stud. 41(5), 685-697 (2007)

Gathmann, C., Schönberg, U.: How general is human capital? A task-based approach. J. Law Econ. 28(1), 1-49 (2010)

Glaeser, E.L., Mare, D.C.: Cities and skills. J. Law Econ. 19(2), 316-342 (2001)

Goos, M., Manning, A.: Lousy and lovely jobs: the rising polarization of work in Britain. Rev. Econ. Stat. 89(1), 118-133 (2007)

Horwitz, S.K., Horwitz, I.B.: The effects of team diversity on team outcomes: a meta-analytic review of team demography. J. Manag. 33(6), 987-1015 (2007)

Hotho, S., Champion, K.: Small businesses in the new creative industries: innovation as a people management challenge. Manag. Decis. 49(1), 29-54 (2011)

Howkins, J.: The Creative Economy: How People Make Money from Ideas. Penguin, UK (2002)

Ingram, B.F., Neumann, G.R.: The returns to skill. Labour Econ. 13(1), 35-59 (2006)

Jara-Figueroa, C., Jun, B., Glaeser, E.L., Hidalgo, C.A.: The role of industryspecific, occupation-specific, and location-specific knowledge in the growth and survival of new firms. Proc. Natl. Acad. Sci. 115(50), 12646-12653 (2018)

Jarvis, H., Pratt, A.C.: Bringing it all back home: The extensification and 'overflowing' of work. Geoforum 37(3), 331-339 (2006)

Jehn, K.A., Northcraft, G.B., Neale, M.A.: Why differences make a difference: a field study of diversity, conflict and performance in workgroups. Adm. Sci. q. 44(4), 741-763 (1999)

Kambourov, G., Manovskii, l.: Occupational specificity of human capital. Int. Econ. Rev. 50(1), 63-115 (2009)

Koster, S., Andersson, M.: When is your experience valuable? Occupationindustry transitions and self-employment success. J. Evol. Econ. 28(2), 265-286 (2018). https://doi.org/10.1007/s00191-017-0528-2

Kremer, M.: The O-ring theory of economic development. Q. J. Econ. 108(3), 551-575 (1993). https://doi.org/10.2307/2118400

Larsen, J.N.: Knowledge, human resources and social practice: the knowledge-intensive business service firm as a distributed knowledge system. Serv. Ind. J. 21 (1), 81-102 (2001)

Lazear, E.P.: Globalisation and the market for team-mates. Econ. J. 109(454), 15-40 (1999)

Madsen, T.L., Mosakowski, E., Zaheer, S.: Knowledge retention and personnel mobility: the nondisruptive effects of inflows of experience. Organ. Sci. 14(2), 173-191 (2003)
Manning, A., Petrongolo, B.: How local are labor markets? Evidence from a spatial job search model. Am. Econ. Rev. 107(10), 2877-2907 (2017)

Maroto-Sánchez, A.: Productivity in the services sector: conventional and current explanations. Serv. Ind. J. 32(5), 719-746 (2012)

Martynovich, M., Henning, M.: Labour force building in a rapidly expanding sector. Ind. Innov. 25(2), 199-227 (2018)

Mas, A., Moretti, E.: Peers at work. Am. Econ. Rev. 99(1), 112-145 (2009)

Mellander, C.: Creative and knowledge industries: an occupational distribution approach. Econ. Dev. q. 23(4), 294-305 (2009)

Miguel-Molina, B., Hervas-Oliver, J.-L., Boix, R., De-Miguel-Molina, M.: The importance of creative industry agglomerations in explaining the wealth of European regions. Eur. Plan. Stud. 20(8), 1263-1280 (2012)

Mincer, J.: Schooling, Experience, and Earnings. National Bureau of Economics Research, New York (1974)

Müller, K., Rammer, C., Trüby, J.: The role of creative industries in industrial innovation. Innovation 11(2), 148-168 (2009)

Mulligan, C.B., Sala-I-Martin, X.: Measuring aggregate human capital. J. Econ. Growth 5(3), 215-252 (2000)

Neal, D.: Industry-specific human capital: evidence from displaced workers. J. Law Econ. 13(4), 653-677 (1995)

Neffke, F.: Coworker complementarity. SSRN J. (2017). https://doi.org/10. 2139/ssrn.2929339

Neffke, F., Henning, M.: Skill relatedness and firm diversification. Strateg. Manag. J. 34(3), 297-316 (2013)

Nooteboom, B.: Learning and Innovation in Organizations and Economies. Oxford University Press, Oxford (2000)

Nooteboom, B., Van Haverbeke, W., Duysters, G., Gilsing, V., van den Oord, Ad.: Optimal cognitive distance and absorptive capacity. Res. Policy 36(7), 1016-1034 (2007)

Olley, G.S., Pakes, A.: The dynamics of productivity in the telecommunications equipment industry. Econometrica 64(6), 1263-1297 (1996)

Östbring, L., Lindgren, U.: Labor mobility and plant performance: on the (dis)similarity between labor- and capital-intensive sectors for knowledge diffusion and productivity. Geogr. Ann. Ser. B Hum. Geogr. 95(4), 287-305 (2013)

Östbring, L., Eriksson, R., Lindgren, U.: Labour mobility and organisational proximity: routines as supporting mechanisms for variety, skill integration and productivity. Ind. Innov. 24(8), 775-794 (2017)

Östbring, L., Eriksson, R., Lindgren, U.: Relatedness through experience: on the importance of collected worker experiences for plant performance. Pap. Reg. Sci. 97(3), 501-518 (2018)

Østergaard, C.R., Timmermans, B., Kristinsson, K.: Does a different view create something new? The effect of employee diversity on innovation. Res. Policy 40(3), 500-509 (2011)

Parent, D.: Industry-specific capital and the wage profile: evidence from the national longitudinal survey of youth and the panel study of income dynamics. J. Law Econ. 18(2), 306-323 (2000)

Parrotta, P., Pozzoli, D., Pytlikova, M.: Labor diversity and firm productivity. Eur. Econ. Rev. 66, 144-179 (2014a)

Parrotta, P., Pozzoli, D., Pytlikova, M.: The nexus between labor diversity and firm's innovation. J. Popul. Econ. 27(2), 303-364 (2014b)

Penrose, E.: The Theory of the Growth of the Firm. Oxford University Press, Oxford (1959)

Perretti, F., Negro, G.: Mixing genres and matching people: a study in innovation and team composition in Hollywood. J. Organ. Behav. 28(5), 563-586 (2007)

Pitcher, P., Smith, A.D.: Top management team heterogeneity: personality, power, and proxies. Organ. Sci. 12(1), 1-18 (2001)

Power, D.: Behind the music. Profiting from sound: a systems approach to the dynamics of the nordic music industry. Oslo: STEP/Nordic Innovation Centre (2003)

Protogerou, A., Kontolaimou, A., Caloghirou, Y.: Innovation in the European creative industries: a firm-level empirical approach. Ind. Innov. 24(6), 587-612 (2017)

Savino, T., Petruzzelli, A.M., Albino, V.: Teams and lead creators in cultural and creative industries: evidence from the Italian haute cuisine. J. Knowl. Manag. 21(3), 607-622 (2017)

Schumpeter, J.A.: The Theory of Economic Development: An Inquiry Into Profits, Capital, Credit, Interest, and the Business Cycle, vol. 55. Transaction Publishers, New Jersey (1934) 
Scott, A.J.: Human capital resources and requirements across the metropolitan hierarchy of the USA. J. Econ. Geogr. 9(2), 207-226 (2008)

Serafinelli, M.: "Good" firms, worker flows, and local productivity. J. Law Econ. 37(3), 747-792 (2019)

Siepel, J., Cowling, M., Coad, A.: Non-founder human capital and the long-run growth and survival of high-tech ventures. Technovation 59, 34-43 (2017)

Solheim, M.C.W., Boschma, R., Herstad, S.J.: Collected worker experiences and the novelty content of innovation. Res. Policy 49(1), 103856 (2020)

Söllner R.: Human capital diversity and product innovation: a micro-level analysis. Jena Econ. Res. Papers 2010(027) (2010)

Stinchcombe, A.L.: Social structure and organizations. Handb. Organ. 7, 142-193 (1965)

Sullivan, P.: Empirical evidence on occupation and industry specific human capital. Labour Econ. 17(3), 567-580 (2010)

Tao, J., Ho, C.-Y., Luo, S., Sheng, Y.: Agglomeration economies in creative industries. Reg. Sci. Urban Econ. 77, 141-154 (2019)

Taylor, A., Greve, H.R.: Superman or the fantastic four? Knowledge combination and experience in innovative teams. Acad. Manag. J. 49(4), 723-740 (2006)

Thompson, W., Thompson, P.: From industries to occupations: rethinking local economic development. Econ. Dev. Comment. 9(3), 12-18 (1985)

Timmermans, B., Boschma, R.: The effect of intra- and inter-regional labour mobility on plant performance in Denmark: the significance of related labour inflows. J. Econ. Geogr. 14(2), 289-311 (2014)
UNESCO.: Creative economy report 2013: special edition: widening local development pathways. UNCTAD New York: United Nations (2013)

Uzzi, B., Spiro, J.: Collaboration and creativity: the small world problem. Am. J. Sociol. 111(2), 447-504 (2005)

Uzzi, B., Mukherjee, S., Stringer, M., Jones, B.: Atypical combinations and scientific impact. Science 342(6157), 468-472 (2013)

Van Ark, B.: Measuring the new economy: an international comparative perspective. Rev. Income Wealth 48(1), 1-14 (2002)

Visintin, F., Pittino, D.: Founding team composition and early performance of university - based spin-off companies. Technovation 34(1), 31-43 (2014)

Williams, K., O'Reilly, C.: The complexity of diversity: a review of forty years of research. Res. Organ. Behav. 21, 77-140 (1998)

Wixe, S.: The impact of spatial externalities: skills, education and plant productivity. Reg. Stud. 49(12), 2053-2069 (2015). https://doi.org/10.1080/00343 404.2014.891729

Wixe, S., Andersson, M.: Which types of relatedness matter in regional growth? Industry, occupation and education. Reg. Stud. 51(4), 523-536 (2016)

Young, A.: Consistency without Inference: Instrumental Variables in Practical Application. Unpublished manuscript, London School of Economics (2019)

\section{Publisher's Note}

Springer Nature remains neutral with regard to jurisdictional claims in published maps and institutional affiliations.

\section{Submit your manuscript to a SpringerOpen ${ }^{\circ}$ journal and benefit from:}

- Convenient online submission

- Rigorous peer review

- Open access: articles freely available online

- High visibility within the field

- Retaining the copyright to your article

Submit your next manuscript at $\boldsymbol{\nabla}$ springeropen.com 